\title{
Roles of Proteoglycans and Glycosaminoglycans in Cancer Development and Progression
}

\author{
Jinfen Wei, Meiling Hu, Kaitang Huang, Shudai Lin and Hongli Du* \\ School of Biology and Biological Engineering, South China University of Technology, Guangzhou 510640, China; \\ 201810107408@mail.scut.edu.cn (J.W.); humeiling@scut.edu.cn (M.H.); huangkaitang@foxmail.com (K.H.); \\ linsd@scut.edu.cn (S.L.) \\ * Correspondence: hldu@scut.edu.cn
}

Received: 19 July 2020; Accepted: 18 August 2020; Published: 20 August 2020

\begin{abstract}
The extracellular matrix (ECM) spatiotemporally controls cell fate; however, dysregulation of ECM remodeling can lead to tumorigenesis and cancer development by providing favorable conditions for tumor cells. Proteoglycans (PGs) and glycosaminoglycans (GAGs) are the major macromolecules composing ECM. They influence both cell behavior and matrix properties through direct and indirect interactions with various cytokines, growth factors, cell surface receptors, adhesion molecules, enzymes, and glycoproteins within the ECM. The classical features of PGs/GAGs play well-known roles in cancer angiogenesis, proliferation, invasion, and metastasis. Several lines of evidence suggest that PGs/GAGs critically affect broader aspects in cancer initiation and the progression process, including regulation of cell metabolism, serving as a sensor of ECM's mechanical properties, affecting immune supervision, and participating in therapeutic resistance to various forms of treatment. These functions may be implemented through the characteristics of PGs/GAGs as molecular bridges linking ECM and cells in cell-specific and context-specific manners within the tumor microenvironment (TME). In this review, we intend to present a comprehensive illustration of the ways in which PGs/GAGs participate in and regulate several aspects of tumorigenesis; we put forward a perspective regarding their effects as biomarkers or targets for diagnoses and therapeutic interventions.
\end{abstract}

Keywords: proteoglycans; glycosaminoglycans; extracellular matrix remodeling; tumor microenvironment; cancer progression

\section{Introduction}

Recently, the increasingly appreciated roles of extracellular matrix (ECM) remodeling, especially its altered mechanics properties, have prompted investigations in cancer [1]. ECM organization is spatiotemporally regulated to control cell behavior and phenotype via complex and regular interactions with matrix molecules. Dysregulation of ECM remodeling contributes to cell fate mainly through changing rigidity and structure; this loss of tissue homeostasis has been linked to many cancer hallmarks including metabolic reprogramming [1], persistent growth signals [2], immunosuppression [3], angiogenesis [4,5], tumor invasion [6] and metastasis [7]. In addition, ECM remodeling-related molecules have also been linked to drug resistance in cancer treatment [8] and have been indicated as diagnosis biomarkers to predict cancer outcome [9]. Overall, the broader roles of ECM remodeling with its properties in cancer initiation and progression should be taken seriously.

To explore how the disturbance of ECM remodeling affect cancer, it is essential to unravel the unique composition and status of its cytoplasmic matrix. As a dynamic structure, the function of ECM in cancer progression is primarily through its components, the deregulated feedback between cellular components and their local TEM, and biomechanical and biochemical properties of the matrix. The unbalance between degradation and secretion of ECM, arranged by ECM-modifying cells and 
ECM proteases, is responsible for disordered ECM remodeling. For example, cancer-associated fibroblasts (CAF) is observed in cancer surrounding matrix and accelerate cell migration and invasion through protease-mediated ECM remodeling [10]. Matrix metalloproteinases (MMPs) reshape the ECM to promote tumor development through various mechanisms including collagen degradation. MMPs stimulate cancer cell proliferation through denaturation of fibrillar collagen in melanoma [11]. Proteoglycans (PGs) and glycosaminoglycans (GAGs) are ubiquitous structural and functional components of ECM. Disorganized expression and distribution of PGs/GAGs lead to dysfunctional ECM and matrix structure collapse [12]. Based on structural features of PGs, composed of a core protein and GAGs, PGs bind several molecules, including various growth factors, adhesive factors, and cytokines, to modulate cancer progression [13]. These effects in cancer may be specific to individual PGs or the complex network between PGs and multiple ECM factors. Any changes in the balance of PGs, GAGs or ECM factors could reflect disorders of the local TME. Thus, understanding the mechanisms of overall or individual PGs/GAGs in the corresponding ECM are vital to understand the theory of driving tumor progression. These elements in in blood or urine represent the most encouraging biomarkers for cancer diagnosis and prognosis.

This review focuses on the importance and novelty of PGs/GAGs with their unique properties in cancer progression at several levels: regulation of cellular metabolism, regulating cell growth and apoptosis signals, managing cell invasion, and participating in immune destruction. We describe the molecular components, classification, metabolic enzymes, and signaling pathways involved in PGs/GAGs and summarize the interactions between PGs/GAGs and TME as well as the ways by which they influence tumor progression and govern responses of tumor cells to therapy. We discuss the potential effects of GAGs/PGs for diagnosis and therapy to prevent or control human cancer. Finally, we highlight challenges that require further investigation and the techniques and model systems that may facilitate this field.

\section{Multiple Characteristics of PGs and GAGs}

Because PGs are composed of a core of proteins covalently linked to GAGs, understanding the structural characteristics and classification of PGs/GAGs is significant for the exploration of the primary biological function in cancer development. Major GAGs include chondroitin sulfate (CS), dermatan sulfate (DS), keratan sulfate (KS), heparan sulfate (HS), and hyaluronic acid (HA) [14]. Except for HA, GAGs can be sulfated and linked to a core protein. For example, to CS is bound aggrecan, neurocan, veriscan, and brevican [15]. PGs are classified according to the chain characteristics of GAGs as well their distribution patterns in human cancer (Table 1).

Generally, the function of PGs/GAGs in cancer development may partly depend on concentration, spatial extension distribution, and temporal duration. Thus, the disordered metabolism of PGs/GAGs is associated with cancer malignancy; for example, the CS synthesis process was more active in several cancer types compared with normal tissues in our earlier study [16]. This was recently reviewed, and it was suggested that pharmacological treatment is a potential option for cancer therapy by targeting the chemical structure, synthesis, and degradation processes of PGs/GAGs $[15,17,18]$. Here, we focus on the important enzymes involved in the degradation processes and summarize the biomarkers associated with these enzymes in cancer (Table 2). Prominent examples are heparanase (HPSE) in degrading HS, hyaluronidase (HYAL) in degrading HA, and MMPs in cleaving PGs. Given the functional diversity of HS chains, such as regulation of the activity of cytokines and growth factors, HPSE-mediated degradation of HS is key to tumor development. Increased HPSE promotes tumor invasion [19] and angiogenesis in pancreatic neuroendocrine tumors and pediatric cancer [20]. Although some HPSE inhibitors have been used in clinical trials, the effects have been unsatisfactory. The main reason may be that inhibitors also target other molecules, causing off-target phenomena [21]. HYAL degrades HA into fragments of different sizes to participate in cancer development, as molecular signals and the level of HYAL expression is often disturbed in cancers. The overexpression of HYAL1 [22] and HYAL2 [23] is observed at the beginning of invasion in human breast cancer and is associated with cancer progression. 
Combining nanovaccine with HYAL has offered a simple and efficient strategy for inducing a powerful anti-tumor effect, indicating it is a promising method in cancer immunotherapy [24]. The MMPs are a family of proteolytic enzymes that degrade many ECM components, including PGs, and display disordered expression in various cancer types, serving as biomarkers for diagnosis and prognosis [25]. In addition to their roles in cell invasion, MMPs play a prominent function in cell proliferation, survival, immune response, and angiogenesis [26]. Once activated, MMP-9, secreted by tumor-associated neutrophils (TANs), cleaves various PGs in the extracellular space, destroying the existing tissue structure, releasing angiogenesis-related factors, and opening up space for expanded tumors to enhance angiogenesis [27]. MMP-9 also protects insulin-like growth factor (IFG) from inactivation via insulin-like growth factor binding protein (IGFBP), thereby providing growth signals for neighboring tumor cells [28]. MMP inhibitors (MMPIs) have been synthesized and tested in various cancer types over the last 20 years [29]; however, trials have been unsuccessful in reducing tumor burden or improving overall survival. We propose that these enzymes in cancer are not up or downregulated, but that there are also spatio-temporal changes throughout cancer development. We suggest that the first step should be to perform trials in early cancers, including measuring expression levels in the early stage. Then, developing drugs to target these enzymes will be very important and challenge investigations. The interaction between PGs/GAGs and fibrillar collagen contributes to fibrosis and affects ECM stiffness, [30] thereby influencing the progression of disease. Collagen XIII, a transmembrane protein, interacts with other ECM molecules, such as perlecan [31], and enhances angiogenesis by activating the JNK pathway and mediating ECM remodeling [32]. However, the roles of PGs/GAGs in cancer-associated ECM stiffness will be another significant research subject.

Table 1. Major PGs grouped according to their location, interaction signals, and their predominant GAGs during tumorigenesis.

\begin{tabular}{|c|c|c|c|}
\hline Specific PG & GAGs & Interaction Signals/Patways & Implication in Cancer Types \\
\hline \multicolumn{4}{|c|}{ Hyalectans } \\
\hline \multirow[t]{4}{*}{ Versican (up) } & CS/DS & Snail/PAPSS2 & Enhances cell migration and metastasis in breast cancer [33]. \\
\hline & & FOXA2-VCAN & Promotes cancer growth and metastasis in ovarian cancer [34]. \\
\hline & & / & Reduces tumor-infiltrating CD8-positive T-cells in cervical cancer [35]. \\
\hline & & $\begin{array}{l}\text { TGF- } \beta / N F-\kappa B \text { signaling } \\
\text { pathway }\end{array}$ & Promotes cancer invasion in ovarian cancer [36]. \\
\hline Aggrecan & $\mathrm{CS} / \mathrm{KS}$ & / & Not studied in cancer. \\
\hline Neurocan (up) & CS & I & Promotes malignant phenotypes in neuroblastoma [37]. \\
\hline Brevican (up) & CS & BEHAB-brevican & $\begin{array}{l}\text { Promotes cell motility in glioma cancer [38]. } \\
\text { Increases aggressiveness in gliomas cancer [39]. }\end{array}$ \\
\hline \multicolumn{4}{|c|}{ Small Leucine-Rich PGs } \\
\hline \multirow[t]{5}{*}{ Biglycan (up) } & CS/DS & l & $\begin{array}{l}\text { Enhances migration and invasion in endometrial cancer [40] and } \\
\text { bladder cancer [41]. }\end{array}$ \\
\hline & & Inducing integrin- $\beta 1$ & Promotes invasiveness in melanoma [42]. \\
\hline & & NF- $\kappa B$ signaling & Promotes chemotherapy resistance in colon cancer [43]. \\
\hline & & VEGF & Promotes angiogenesis in colon cancer [44]. \\
\hline & & FAK signaling pathway & Enhances invasion in gastric cancer [45]. \\
\hline \multirow[t]{3}{*}{ Decorin (down) } & CS/DS & E-cadherin & Inhibits growth and migration in colon cancer [46]. \\
\hline & & PDCD4/microRNA-21 & $\begin{array}{l}\text { Boosts inflammatory activity and suppresses tumor growth in blood } \\
\text { cancer [47]. }\end{array}$ \\
\hline & & TGF- $\beta$ pathway & Inhibits invasion and metastasis in non-small cell lung cancer [48]. \\
\hline Lumican (down) & KS & AMPK signaling pathway & Augments chemotherapy cytotoxicity in pancreatic cancer [49]. \\
\hline
\end{tabular}


Table 1. Cont

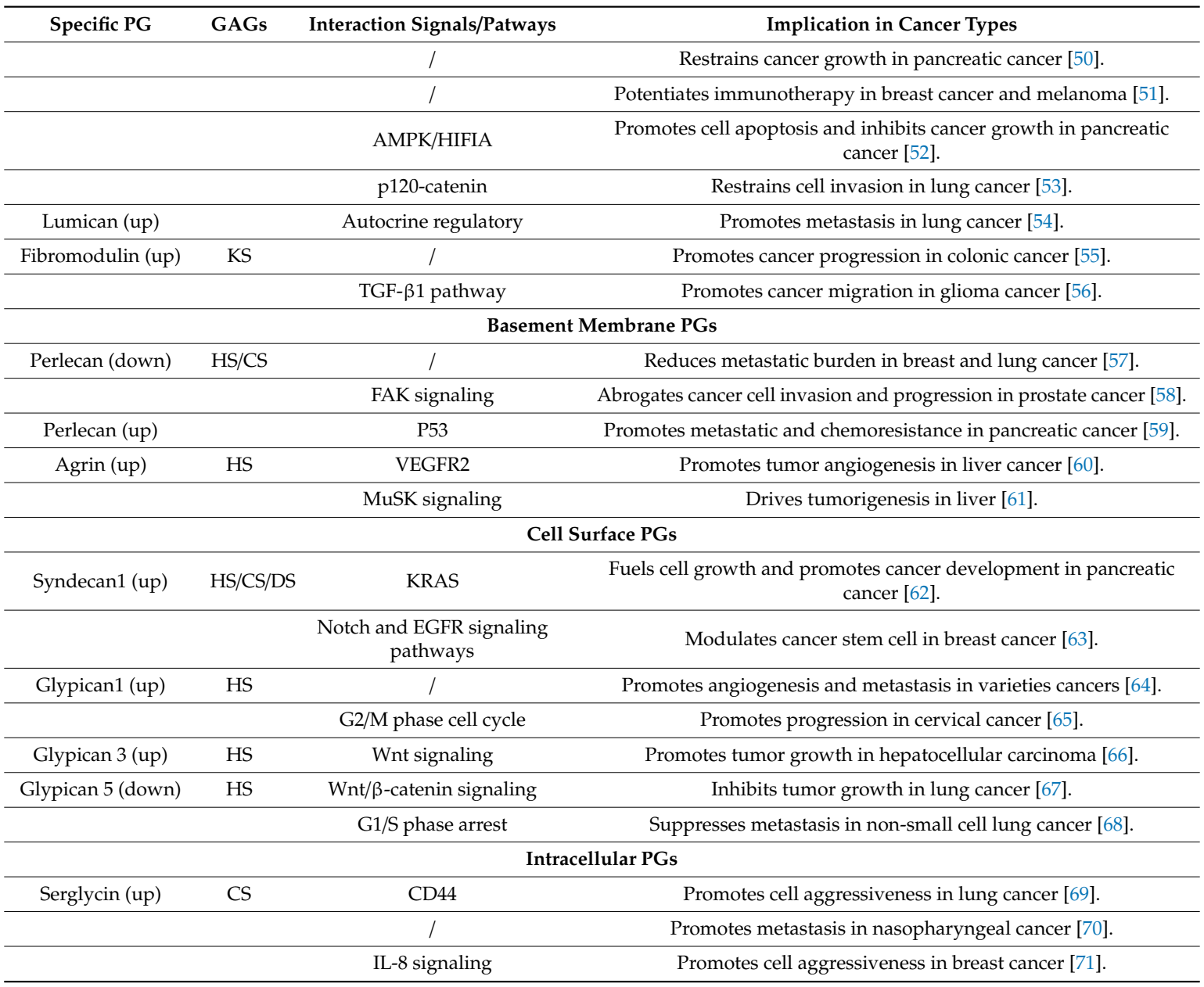

Note: "up" and "down" indicate that the specific PG is upregulated and downregulated, respectively, in cancer cells/tissues compared with normal ones in the corresponding studies. "I" indicates that the interaction signals or pathways are not shown in these studies.

Table 2. The values of PGs/GAGs and related enzymes in pre-clinical and clinical studies of cancer.

\begin{tabular}{|c|c|c|}
\hline Name & Samples & Potential Clinical Applications in Cancer \\
\hline \multicolumn{3}{|c|}{ PGs } \\
\hline \multirow[t]{12}{*}{ Versican } & Tissues $(n=84)$ & Prognosis for renal carcinoma [72] \\
\hline & Tissues $(n=52,62,456 / 453,89)$ & Prognosis for colon cancer $[73,74]$ \\
\hline & Blood $(n=27,12,31)$ & Diagnosis for epithelial ovarian cancer [75] \\
\hline & Blood $(n=30)$ & Diagnosis for multiple myeloma [76] \\
\hline & Tissues $(n=134 / 104)$ & Prognosis for gastric cancer $[77,78]$ \\
\hline & Tissues $(n=142 / 212)$ & Prognosis for non-small cell lung cancer $[79,80]$ \\
\hline & Tissues $(n=50,19,31)$ & Diagnosis for hepatocellular carcinoma [81] \\
\hline & Tissues $(n=139)$ & Prognosis for oral squamous cell carcinoma [82] \\
\hline & Tissues $(n=80 / 58)$ & Prognosis for breast cancer $[83,84]$ \\
\hline & Tissues $(n=111 / 111)$ & Prognosis for ovarian cancer $[85,86]$ \\
\hline & Tissues $(n=167)$ & Prognosis for endometrial cancer [87] \\
\hline & Tissues $(n=43)$ & Prognosis for prostate cancer [88] \\
\hline Biglycan & Tissues $(n=12,427)$ & Prognosis for prostate cancer [89] \\
\hline
\end{tabular}


Table 2. Cont.

\begin{tabular}{|c|c|c|}
\hline Name & Samples & Potential Clinical Applications in Cancer \\
\hline & Tissues $(n=10)$ & Prognosis for gastric cancer [90] \\
\hline & Tissues $(n=287)$ & Prognosis for colorectal cancer [91] \\
\hline & Tissues $(n=62 / 170)$ & Diagnosis for esophageal adenocarcinoma $[92,93]$ \\
\hline & Tissues $(n=52)$ & Prognosis for endometrial cancer [94] \\
\hline & Tissues $(n=53)$ & Prognosis for pancreatic adenocarcinoma [95] \\
\hline \multirow[t]{6}{*}{ Decorin } & Tissues $(n=24)$ & Diagnosis for invasive ductal carcinoma [96] \\
\hline & Tissues $(n=16)$ & Prognosis for malignant peripheral nerve sheath tumor [97] \\
\hline & Tissues $(n=83,6,32,145 / 64)$ & Prognosis for lung adenocarcinoma $[98,99]$ \\
\hline & Tissues $(n=16)$ & $\begin{array}{l}\text { Prognosis for oral cancer and response to S-1 neoadjuvant } \\
\text { chemotherapy [100] }\end{array}$ \\
\hline & Plasma $(n=275)$ & Diagnosis for esophageal squamous cell carcinoma [101] \\
\hline & Tissues $(n=140)$ & Prognosis for breast cancer [102] \\
\hline \multirow[t]{4}{*}{ Lumican } & Tissues $(n=13)$ & Diagnosis for lung adenocarcinoma [103] \\
\hline & Tissues $(n=131)$ & Prognosis for pancreatic cancer [104] \\
\hline & Tissues $(n=158)$ & Prognosis for colorectal cancer [105] \\
\hline & Tissues $(n=102)$ & $\begin{array}{l}\text { Prognosis for lung adenocarcinoma and squamous cell } \\
\text { carcinoma [106] }\end{array}$ \\
\hline Perlecan & Tissues $(n=511)$ & Prognosis for oligodendroglioma [107] \\
\hline \multirow[t]{2}{*}{ Agrin } & Tissues $(n=123)$ & Prognosis for oral cancer [108] \\
\hline & Tissues $(n=86)$ & Prognosis for lung adenocarcinoma [109] \\
\hline \multirow[t]{3}{*}{ Collagen XVIII } & Tissues $(n=105)$ & Prognosis for hepatocellular carcinoma [110] \\
\hline & Tissues $(n=221 / 94)$ & Prognosis for lung carcinoma $[111,112]$ \\
\hline & Tissues $(n=118)$ & Prognosis for gastric carcinoma [113] \\
\hline \multirow[t]{2}{*}{ Syndecan1 } & Tissues $(n=111)$ & Prognosis for ovarian cancer [86] \\
\hline & Serum $(n=75)$ & Prediction of docetaxel resistance in prostate cancer [114] \\
\hline Syndecan 3 & Blood $(n=27,12,31)$ & Diagnosis for epithelial ovarian cancer [75] \\
\hline \multirow[t]{4}{*}{ Glypican1 } & Urine $(n=203)$ & Diagnosis for prostate cancer [115] \\
\hline & Tissues $(n=240 / 186 / 62)$ & Prognosis for pancreatic cancer [116-118] \\
\hline & Tissues $(n=53)$ & Diagnosis dissemination and prognosis for glioblastomas [119] \\
\hline & Tissues $(n=175)$ & Prognosis for esophageal squamous cell carcinoma [120] \\
\hline \multirow[t]{3}{*}{ Glypican3 } & Tissues $(n=2336)$ & Diagnosis for hepatocellular cancer [121] \\
\hline & Blood $(n=85)$ & Prognosis for hepatocellular cancer [122] \\
\hline & Tissues $(n=106)$ & Prognosis for pancreatic ductal cancer [123] \\
\hline \multirow[t]{2}{*}{ Glypican5 } & Tissues $(n=160)$ & Prognosis for prostate cancer [124] \\
\hline & Tissues $(n=40 / 198)$ & Prognosis for lung adenocarcinoma $[67,68]$ \\
\hline \multirow[t]{2}{*}{ Serglycin } & Tissues $(n=112)$ & Prognosis for nasopharyngeal carcinoma [125] \\
\hline & Tissues $(n=127)$ & Prognosis for hepatocellular carcinoma [126] \\
\hline \multicolumn{3}{|r|}{ GAGs } \\
\hline Plasma GAGs & Blood $(n=175)$ & Diagnosis and prognosis for renal cell cancer [127] \\
\hline \multirow[t]{2}{*}{ CS } & Tissues $(n=130 / 169)$ & Prognosis for breast cancer [128] \\
\hline & Tissues $(n=289 / 148)$ & Prognosis for ovarian cancer $[129,130]$ \\
\hline HS & Tissues $(n=162)$ & Prognosis for gastric carcinoma [131] \\
\hline \multirow[t]{2}{*}{ HA } & Blood $(n=44)$ & Diagnosis and prognosis for prostate cancer [132] \\
\hline & Blood $(n=212 / 334)$ & Prognosis for breast cancer [133] \\
\hline
\end{tabular}


Table 2. Cont.

\begin{tabular}{|c|c|c|}
\hline \multirow[t]{9}{*}{ Name } & Samples & Potential Clinical Applications in Cancer \\
\hline & Serum $(n=51)$ & Prognosis for acute myeloid leukemia [134] \\
\hline & Urine $(n=513)$ & Diagnosis for bladder cancer [135] \\
\hline & Serum $(n=63)$ & Diagnosis for upper gastrointestinal cancers [136] \\
\hline & Cytosol $(n=120)$ & Prognosis for colorectal cancer [137] \\
\hline & Tissues $(n=46) /$ Sputum $(n=25)$ & Diagnosis and prognosis for lung cancer [138] \\
\hline & Serum/pleural $(n=96)$ & Diagnosis and prognosis for malignant mesothelioma [139] \\
\hline & Serum $(n=506)$ & Prognosis for liver cancer in hepatic resection [140] \\
\hline & Tissues $(n=45)$ & Prognosis for nerve sheath tumor [141] \\
\hline \multicolumn{3}{|c|}{ Enzymes } \\
\hline \multirow[t]{4}{*}{ HPSE } & Tissues $(n=182)$ & Prognosis for glioma [142] \\
\hline & Serum $(n=156)$ & Diagnosis for breast cancer [143] \\
\hline & Serum $(n=177)$ & Diagnosis for ovarian cancer [144] \\
\hline & Tissues $(n=81)$ & Prognosis for oral mucosal melanoma [145] \\
\hline \multirow[t]{4}{*}{ HYAL-1 } & Tissues $(n=407 / 178)$ & Prognosis for bladder cancer $[146,147]$ \\
\hline & Tissues $(n=70)$ & Prognosis for prostate cancer [148] \\
\hline & Urine $(n=513)$ & Diagnosis for bladder cancer [149] \\
\hline & Tissues $(n=34)$ & Prognosis for colorectal cancer [150] \\
\hline \multirow[t]{3}{*}{ HAS1 } & Tissues $(n=278)$ & Prognosis for breast cancer [151] \\
\hline & Tissues $(n=31)$ & Prognosis for colon cancer [152] \\
\hline & Tissues $(n=287)$ & Prognosis for prostate cancer [153] \\
\hline HAS2 & Tissues $(n=407)$ & Prognosis for bladder cancer [146] \\
\hline \multirow[t]{2}{*}{ HAS3 } & Tissues $(n=407)$ & Prognosis for bladder cancer [146] \\
\hline & Tissues $(n=278)$ & Prognosis for breast cancer [151] \\
\hline MMP2 & Tissues $(n=1266)$ & Prognosis for oral cancer [154] \\
\hline MMP3 & Urinary $(n=70)$ & Diagnosis and prognosis for bladder cancer [155] \\
\hline MMP9 & Tissues $(n=1266)$ & Prognosis for oral cancer [154] \\
\hline MMP14 & Tissues $(n=456)$ & Prognosis for colorectal cancer [156] \\
\hline MMP16 & Tissues $(n=375)$ & Prognosis for gastric cancer [157] \\
\hline \multicolumn{3}{|c|}{ Effectors } \\
\hline \multirow[t]{7}{*}{ RHAMM } & Tissues $(n=383)$ & Prognosis for large cell lung cancer [158] \\
\hline & Tissues $(n=64)$ & Prognosis for kidney cancer [159] \\
\hline & Tissues $(n=33)$ & Prognosis for ovarian cancer [160] \\
\hline & Tissues $(n=223)$ & Prognosis for colorectal cancer [161] \\
\hline & Tissues $(n=89)$ & Prognosis for endometrial cancer [162] \\
\hline & Tissues $(n=72)$ & Prognosis for B-cell chronic leukemia [163] \\
\hline & Tissues $(n=210)$ & Prognosis for multiple myeloma [164] \\
\hline \multirow[t]{5}{*}{ CD44 } & Tissues $(n=64)$ & Prognosis for kidney cancer [159] \\
\hline & Tissues $(n=94)$ & Prognosis for bladder cancer [165] \\
\hline & Tissues $(n=145)$ & Prognosis for colorectal adenocarcinomas [166] \\
\hline & Tissues $(n=158 / 333)$ & Prognosis for early gastric cancer $[167,168]$ \\
\hline & Tissues $(n=278)$ & Prognosis for breast cancer [169] \\
\hline
\end{tabular}

\section{GAGs and PGs: Connecting the Cell to the ECM}

In addition to being major components of the ECM, PGs play roles in signal transduction by binding molecules within ECM, thereby affecting cancer progression. PGs' core proteins interact with 
various receptors and glycoproteins including CD44 [69], EGFR [170], and VEGFR [171]. Binding with TGF- $\beta$, EGFR, HGFR, IGFR, and other growth factors, decorin weakens their downstream signals and inhibit tumor cell proliferation [172,173]. Unlike decorin, cell surface PGs are involved in promoting cell growth by interacting with growth factors and affecting proliferation signaling. As a sensor to the ECM mechanical properties, syndecan- 4 binds to fibronectin to activate a series of signals, including the MAPK pathways, leading to cell proliferation and migration [174]. Syndecan-1, a coreceptor and cooperator with HGF [175] and HER2 [176], respectively, activates proliferative signals and improves cancer cell survival. Perlecan interacts with various cytokines including FGF and VEGF families through its core protein and the HS chains to affect angiogenesis and cell growth $[177,178]$. HSPG, harbored by CD43, enhances CXCL14 binding properties to glycoproteins, thereby leading to cell proliferation and tumor invasion in lung cancer [179]. CD43, a cancer-associated glycoprotein, is involved in various cancer types, where it performs several functions, including immune responses $[180,181]$, cell proliferation [182], and cell growth and viability [183]. As other key macromolecules in ECM, alterations of glycoproteins, contributed by aberrant glycosylation patterns, are also observed in cancer. For more information about glycosylation in cancer please refer to the review in Reference [184].

GAG chains also bind several factors to affect cancer progression. Although HS and CS bind growth factors or chemokines to regulate corresponding functions [185], HA is the most studied and important GAGs that deserve attention. In this section, we focus on HA-binding factors and point to the key signals in Figure 1. Compared with other GAGs forming PG, the basic structure of HA is a large polysaccharide that can interact with various membrane receptors and cell surface glycoproteins, including CD44, HMMR, EMMPRIN, and LYVE-1, to control tumor cell fate. The interaction of HA-CD44 greatly influences the key functional status of tumor cells in various aspects including promoting cell proliferation and enhancing chemo resistance through regulating PI3K/Akt and MAPK signal pathways $[186,187]$. Additionally, blocking HA-CD44 interaction is implicated in P53-dependent apoptosis in human lung cancer cells [188]. Another HA receptor, LYVE-1, with a similar structure to CD44, is also associated with chemoresistance for virus-mediated lymphoma [189]. LYVE-1 serves crucial roles in activating signal transduction pathways, including PIAK/Akt and NF- $\mathrm{kB}$ that regulate apoptosis and cell survival $[190,191]$. Based on these findings, HA appears to participate critically in tumor progression by interacting with receptors and acting on intracellular signaling pathways. Recent research has indicated that mechanical properties affect cell behavior in several circumstances including driving invasion and metastasis of cancer cells [10]. The structural and functional alterations in ECM composition define tumor-promoting physical and biomechanical properties of the ECM, such as stiffness, thereby allowing cancer cells to respond to mechanical stimuli and find escape mechanisms in the surrounding TME [192]. Cancer cells interact with and respond to these pressures, including ECM stiffness, through transmembrane PGs, such as syndecan, that induce MAPK signals to deal with these stresses and lead to cell survival and migration [174]. GAGs contribute ECM stiffening by regulating collagen structures, thereby controlling tumor growth [193]. Taken together, the data suggest that disordered interactions between PGs/GAGs and various molecules with altered expression and distribution are at least partially responsible for reconstructed ECM in the TME. It is suggested that combined targeting PGs/GAGs with their connected signaling pathways is an effective approach to improve therapeutic efficacy. This phenomenon can be demonstrated, for example, by co-treatment with lumican which enhances the cytotoxicity of chemotherapy by blocking AMPK signaling pathways in several models of pancreatic ductal cancer (PDAC) [49]. 
A

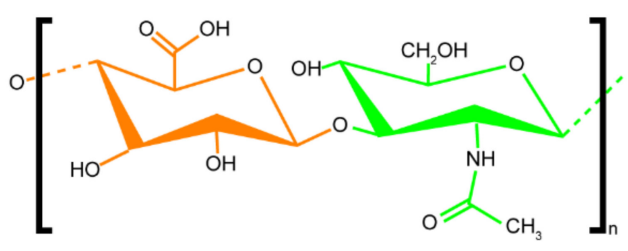

B

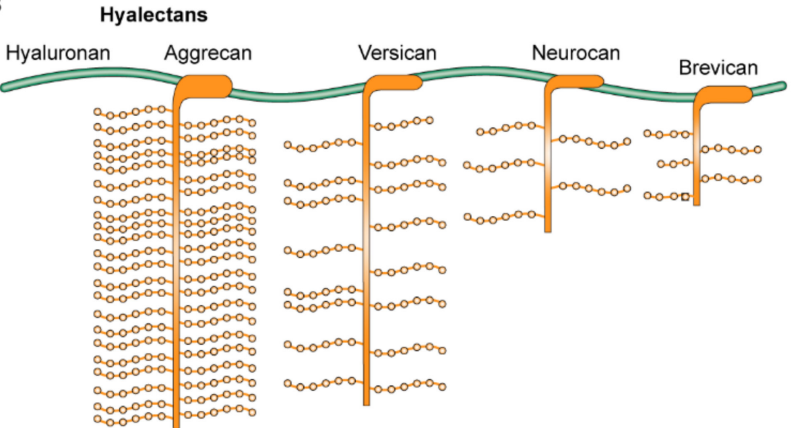

c

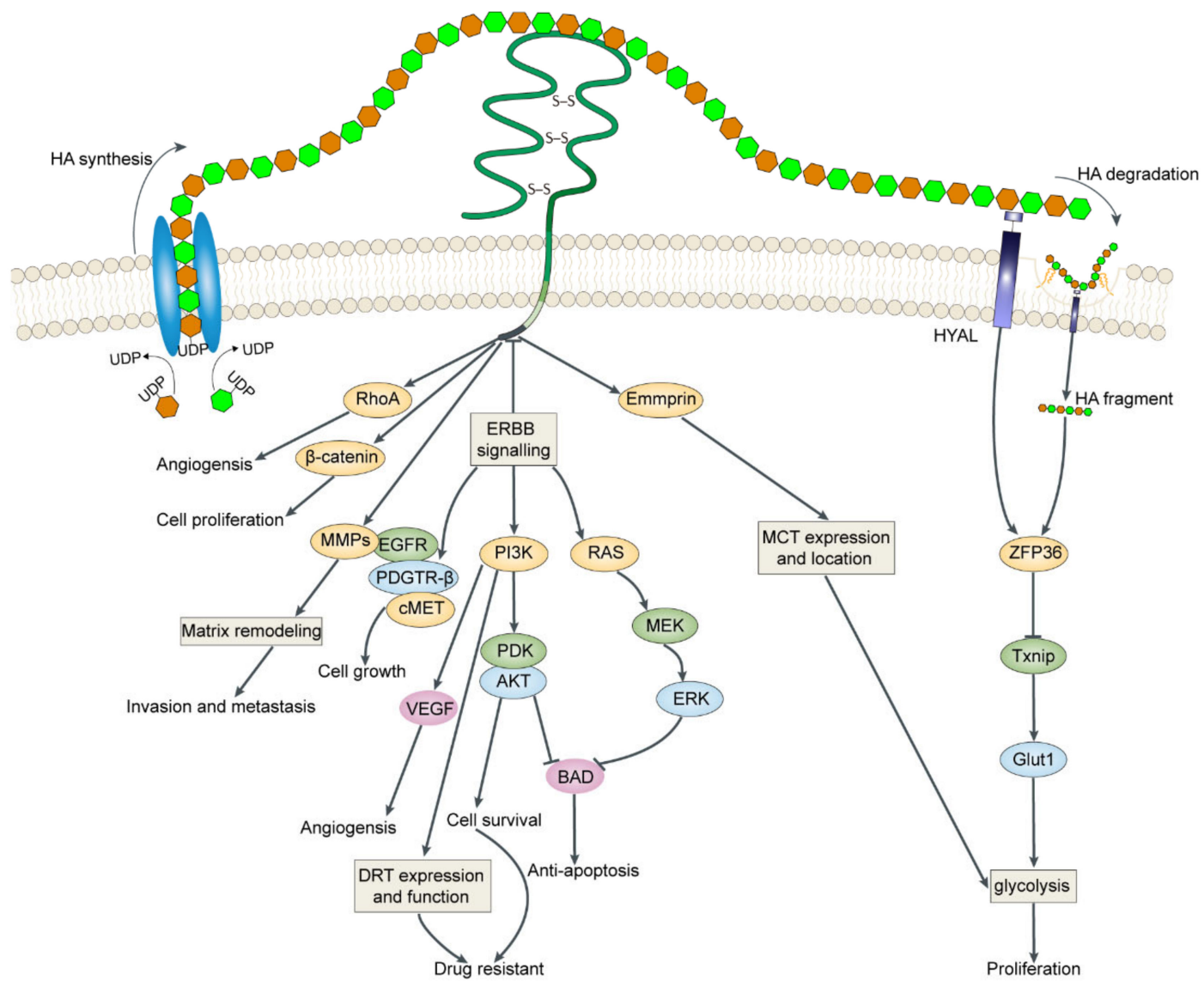

Figure 1. HA in tumor development. (A) Structure of HA. (B) The interactions between HA and hyalectans (aggrecan, versican, neurocan, and brevican) in the ECM. (C) The synthesis, degradation process, and roles in cancer progression of HA. HA is synthesized by HAS1, HAS2 and HAS3 in cell membrane. CD44 binds to HA to transduce signaling and its downstream effectors. HA-CD44 binds RhoGTPases and $\beta$-catenin to induce angiogenesis and proliferation. HA-CD44 stimulates MMP production and MMP presentation on cell surfaces and thus leads to cell invasiveness and metastasis. HA-CD44 induces ERBB2 activity to active PI3K/AKT, RAS/ERK, and EGFR signals. PI3K can activate EGFR/PDGTR/cMET to promote cell growth. PI3K signaling regulates DRT expression and function also phosphorylates AKT to activate cell-survival signaling thus inducing drug resistance. PI3K/AKT and RAS/ERK signal phosphorylate, the pro-apoptotic factor BAD, to inactivate it. HA-CD44 interacts with emmprin which locate MCTs on the cell membrane to increase the release of lactate and glycolysis. HA is degraded by HYAL into smaller molecules. HA fragment signals through RTKs to activate ZFP36, causing TXNIP degradation, hindering TXNIP-mediated GLUT1-internalization, leading to more glucose transport and prompting glycolysis to motivate cancer cell proliferation. HAS: hyaluronan synthase; HA: hyaluronan; MMP: metalloproteinase; DRT: drug-resistance transporter; HYAL: hyaluronidase; RTKs: receptor tyrosine kinases. 


\section{Dysregulation of GAGs/PGs in Cancer Progression}

Several studies suggest that GAGs/PGs have important roles in cancer development, including regulation of metabolic patterns, angiogenesis and distant metastases, and treatment resistance [194], even playing roles in adaptive responses to stresses such as hypoxia and acidosis in the TME [195].

\subsection{Metabolic Reprogramming}

Metabolic deregulation is a hallmark of cancer. Increased glycolysis provides energy for cell growth and its intermediate products for macromolecular synthesis to cells, thereby enhancing malignancy [196]. Metabolic activities are affected by many biological properties, including ECM remodeling, and this effect is beginning to be deciphered in recent studies. The persistence of high glycolytic rates is shown in cancer to resist the pressure brought by the continually altered mechanical character of ECM [1]. Increased ECM stiffness contributed by CAFs enhances cell glutaminolysis to support the metabolic needs of tumor proliferation in several cancer types [197]. The close links between metabolic reprogramming and specific perturbations in PGs/GAGs, especially HA, are beginning to be established (Figure 1). HA fragments broken down by HYAL signal through receptor tyrosine kinases (PTKs) to induce downstream signaling, leading to increased glucose transport and induction of glycolysis to accelerate migration of cancer cells [198]. In addition to extensive conventional effects in malignancy, the interactions of HA-CD44 also play cooperative roles in tumor glycolysis. Antagonists of HA-CD44 interactions rapidly inhibit lactate production in breast cancer cells. Emmprin, a member of the immunoglobulin family, interacts with monocarboxylate transporters (MCTs) at the plasma membrane to increase glycolysis and enhance malignancy [199]. Similarly, another study suggested that interactions among HA, CD44, and emmprin contribute to cancer cells with glycolytic phenotype and other malignant properties [200]. In addition to HA, increased levels of PGs can also regulate glycolysis to influence cancer progression, these include lumican, an anti-proliferative PG that inhibits cell glycolysis by suppressing EGFR and its downstream signals in PDAC [104]. The CD36-glypcian 4 interaction inhibits the $\beta$-catenin-c-MYC signaling axis mediating glycolysis to repress colorectal cancer by ubiquitination of GPC4 [201].

We conclude that the precise signaling events between PGsß/GAGs and metabolism depend on the direct interaction with effectors, such as membrane glycoprotein, and these links between GAG chains and glucose metabolism might further explain that the matrix is a way to coordinate these interdependent processes. ECM remodeling caused by PG/GAG disorders serves as a key extrinsic site of cell metabolic regulation; therefore, we propose that PGs/GAGs can be considerable therapeutic targets in ECM to normalize glucose metabolic disorders responsible for cancer progression.

\subsection{Tumor Cell Proliferation and Growth}

Persistent cell proliferation signaling is another cancer hallmark. PGs/GAGs are involved in regulating tumor cell proliferation through modulating growth factors and signals. CS inhibits PTEN, a cancer suppressor, to activate melanoma cell proliferation [202]. Abnormal abundance of KS is highly associated with accelerated proliferation in tumors such as lymphoma [203], astrocytic tumors [204], and glioblastoma [205]. Growth signals are activated by sulfated KS that induces the MAPK and PI3K pathways in lymphoma cells [203]. HS, presenting on cell surfaces and in matrix, is involved in modulating cell growth. In one study, HS acted as a receptor for a growth-related ligand to promote cancer growth [206]. We suggest that, in the future, combining anti-GAGs drugs with proliferative inhibitors may represent an attractive approach in clinical treatments for cancer therapy.

Via interactions with signaling molecules, PGs cooperate with ECM proteins and cell proliferation-related signaling events, including NF- $\mathrm{KB}$ and EGFR signaling pathways, to regulate tumor growth. Versican is a large CSPG involved in regulating cell proliferation in several cancer types. The matrix versican secreted by stroma cells promoted cancer cell proliferation by interacting with 
HA-CD44 signals in ovarian cancer [36]. Biglycan knock-out led tumor cell apoptosis by decreasing cyclin A and cyclin D1 expression in colon cancer [207]. As mentioned above, lumican, an antiproliferative PG, inhibited cell growth potential in melanoma cells $[208,209]$ and inhibited cell proliferation in animal models of melanoma [210] and pancreatic cancer [104]. Additional supplementation with lumican suppressed cell growth by binding to EGFR and, subsequently, blocked downstream pathways in pancreatic cancer [50]. Perlecan, another antiproliferative PG, bound growth factors and blocked tumor cell proliferation through both its GAG chains and core protein [211]. Stroma cell-derived perlecan slowed the proliferative potential, thereby reducing tumor burden in lung and breast cancer [57]. Cell surface PGs also participate in regulating cell proliferation [212]; this includes the syndecan family [213]. One study showed that syndecan-1 was critical for tumor presence and growth, serving as a KRAS activator, and this suggested that it was a potential therapeutic target in PDAC treatment [62]. Serglycin, the only intracellular PG, promoted tumor cell growth through interacting with CD44, and it was found that combining targeting serglycin and CD44 could be an effective therapy [69]. Based on a growing body of studies, specific PGs with different core protein and GAG chain can be used as tumor suppressor or oncoprotein to influence cell growth, providing promising therapeutic strategies for cancer.

\subsection{Angiogenesis}

Sustained angiogenesis is another hallmark of cancer, and angiogenesis allows tumors to grow due to the access to an ample nutrient supply which can be regulated by several angiogenic factors including VEGF and FGF-2 [214]. The significant roles of ECM remodeling in tumor angiogenesis have been discussed and highlighted in a previous review [215]. We concentrate on the current knowledge regarding how PGs/GAGs regulate angiogenesis in cancer. HA is the key link between ECM-cancer-angiogenesis [216]. HA overproduction within the ECM rapidly develops aggressive breast carcinomas in which cancer cells engage in more vascularization [217]. Generally, HA interacts with versican, the most abundant type of PG, to affect angiogenesis [218]. Matrix versican, secreted by stromal cells, promoted cancer growth by inducing angiogenesis in lung cancer [219]. Biglycan contributes to tumor growth partly due to the fact of its capability to stimulate inflammation-related angiogenesis. For example, high levels of biglycan triggered angiogenesis by upregulation of VEGF and the TLR signaling pathway in colon cancer [44] and gastric cancer [220]. As another effective regulator in angiogenesis, perlecan promotes angiogenesis by activating vascular-related factors based on its HS chain [221] and by protecting angiogenic factors from specific inhibitory biological functions such as proteolysis [222]. A high level of matrix agrin is vital for angiogenesis; this was confirmed by a study in which agrin stimulated angiogenesis by upregulating VEGFR2 levels in liver cancer [60]. Other PGs, such as glypicans, also play a part in angiogenesis by regulation of angiogenic factors. Endothelial cell-derived glypican-1 promoted angiogenesis by regulating FGF2 and VEGFA in pancreatic cancer [223]. Studying the specific mechanisms of the interaction between PG and these angiogenesis factors provides more possibilities for us to choose appropriate inhibitors to block angiogenesis in cancer treatment.

\subsection{Tumor Cell Invasion and Metastasis}

Cell invasion and metastasis is associated with tumor recurrence, poor survival, and mortality. ECM remodeling is a major event that promotes cancer invasion by creating suitable conditions including inducing podosome biogenesis for facilitating cell invasion in breast cancer [224]. PGs/GAGs regulate cancer metastasis in several aspects by a specific PG/GAG or collective activity of PGs/GAGs. A research method developed to calculate the scores defining measured GAG abundance robustly predicted cancer cell metastasis in renal cancer [225]. Alteration in one individual GAG also led to tumor metastasis; for example, elevated HS biosynthesis in a matrix highly correlated with cell migration [226]. Conventionally, the role of HS in cancer metastasis is mainly due to the fact of its interaction with growth factors as well as its regulation of the epithelial-to-mesenchymal transition (EMT) which is the 
first signal of metastasis [227]. In addition to conventional functions, some novel characteristics of HS in cancer metastasis have also been reported. HSPG activates cancer's metastatic potential to promote tumor progression by acting as a stress sensor to adapt the cellular response to hypoxic stress within the TME [195]. Studies showed that expression, abundance, structural changes, cell-derived sources, and location of PGs influence cancer metastasis. Sulfation of glycan promoted tumor metastasis in lung cancer [228]. High expression of versican enhanced cell migration and metastasis in several breast cancer cell lines [33]. Myeloid cell-derived versican, a macrophage activator, facilitated cancer metastatic growth in lung cancer [229]. Fibroblast-derived syndecan-1 is vital to promote invasion and metastasis in breast cancer cells [230]. Serglycin is an intracellular PG that aggregates with CD44 to promote lung cancer cell migration by triggering the CD44/NF-KB/CLDN1 [69] and CD44/Rho/Src/FAK axes [231]. These significant studies allow us to further understand the cell source, abundance, location, and expression levels of PG/GAGs and to explore more deeply the mechanisms of regulatory interactions between PGs/GAGs and ECM signaling. These will help us identify better treatments to block cancer metastasis in a timely fashion, thereby improving survival rates.

\subsection{Immune Surveillance}

Tumor progression is also regulated and supervised by immune infiltration (TIL) and immune cell ability for eliminating tumors. Immune surveillance is partly influenced by dynamic changes of ECM, as is illustrated by a study in which constituents' alteration of ECM promoted tumor survival and affected the motility of $\mathrm{T}$ immune cells in melanoma [7]. Increased ECM stiffness contributed by high collagen density in breast cancer ECM reduced T-cell cytotoxic activity and supported cancer progression [232]. According to previous studies, the role of PGs/GAGs in regulating the supervisory function of immune cells depends on their particular molecular structure and the intimate connection between PGs/GAGs and immune signaling; for example, changing the glycoprotein form of various immune-related cytokines enhanced immune escape in several types of solid tumors [233]. GAGs are major factors in tumor immunity, for example, HS as a candidate for therapeutic cancer vaccination against various malignancies [234]. The interaction of HA fragments with CD44 in the ECM weakened the anti-tumor ability of cytotoxic T lymphocytes by reducing Fas-mediated apoptosis in lung cancer [235]. Tumor-derived HA fragments contributed to immune escape by "instigating" dendritic cells in a special pattern inducing apoptosis of autologous T-cells in several tumors [233]. Recently, HA-based hydrogel has been engineered to T-cell activation by presenting the two stimulatory signals [236].

Versican, a large matrix PG with immunoregulatory activity highly expressed in the TME matrix, is known to reduce the tumor-infiltrating level (TIL) of CD8+ T-cells and promote cell migration in cervical cancer [35]. It is expected that removing versican could suppress its cancer-promoting effect; for example, increasing versican proteolysis enhances the CD8+ T-cell infiltration in colorectal cancer [237]. Acting as TLR ligand, a high level of versican also regulates the immunosuppressive ability of myeloid-derived suppressor cells (MDSCs) to enhance the immune escape [238]. These studies provide a way for investigating versican as a novel immune biomarker in solid cancers. Intriguingly, decorin reduced the abundance of anti-inflammatory molecules and increased proinflammatory molecules, thereby boosting the immune response and reducing tumor growth. Decorin signaling suppressed tumor growth by stimulating PDCD4, shifting the immune response toward a proinflammatory phenotype in a tumor xenograft model [47]. In addition, to direct immunotherapy applications, considering the influences of the environment on treatment effect is vital to studying how to apply combination targets to immune stimulation in the future. Therefore, finding a reasonable combined targeting strategy will not only improve immune responses and avoid immune escape but will also block cancer progression directly. 


\section{Clinical Features}

\subsection{GAGs and GPs in Diagnosis and Prognosis}

In addition to the critical roles in malignancies at multiple aspects described above, PGs/GAGs also have value for clinical diagnosis and prognosis in various cancer types. Because GAGs play roles in the ECM, researchers supposed that alteration of their abundances would reflect changes in body fluids, i.e., the blood and urine of cancer patients, e.g., levels of GAGs in plasma predicted the tumor metastatic capacity in renal cancer [225]. High levels of KS appeared in female genital cancer suggesting that KS might be a biomarker for diagnosis of this cancer [239]. High levels of CS showed prognostic capacity in breast [128] and ovarian cancers [130]. High expression levels of HS signaled poor prognosis in patients with gastric carcinoma [131]. Higher levels of HA were associated with poor survival in patients with breast cancer [133], acute myeloid leukemia [134], and prostate cancer [132]. Elevated serum levels of HA can be a diagnostic biomarker for patients with prostate cancer [132], upper gastrointestinal cancers [136], and mesothelioma [139]. The diagnosis and prognosis roles of HA in other cancer types are presented in Table 2.

PGs are prominent molecules in tumor diagnosis. The increased versican levels in cancer patients were shown to diagnose the occurrence of epithelial ovarian cancer [75] and multiple myeloma [76]. Elevated levels of glypican-1 were associated with poor survival in patients with PDAC [117]. Because glypican-1 is overexpressed in several cancer types [116,117], it can be a biomarker for detection of prostate cancer [115] in urine and for the dissemination of glioblastoma [119]. The abundance of glypican-1 positively correlates with disease severity in patients, whether they have received surgical treatment or not, suggesting that glypican is a surgery-independent, inherent diagnostic biomarker of pancreatic cancer [240]. Other studies relevant to prognosis and diagnostic capabilities of PGs/GAGs are summarized in Table 2. All these studies provide possible clinical values for early detection and prognosis of PGs/GAGs, especially those detected in urine or blood, and help design potential cancer treatments. Therefore, acceleration of the development of research tools in detection of PGs/GAGs, especially determination whether disordered PGs/GAGs can be secreted into the blood or excreted into the urine, will make it easier to detect cancer in early stages and will represent the most valuable biomarkers for cancer diagnosis.

\subsection{GAGs and PGs in Cancer Treatment}

In addition to their diagnostic and prognostic capabilities, PGs/GAGs play roles in therapy resistance in various therapeutic processes and are used as effective therapeutic targets for inhibition of cancer progression. Accordingly, drugs have been produced targeting GAGs' metabolic processes including synthesis, degradation, and related enzymes as well as targeting their specific structures [241]. High levels of HA in the TME are related to more severe and advanced cancer states [242,243], reflected in promoting tumor progression and participating in therapeutic resistance. The role of HA in drug resistance is contributed by disordered interaction between HA-ECM factors in the TME. Large quantities of HA in ECM stimulate interactions with CD44 to cause chemoresistance in patients with head and neck cancer patients [244]. HA activates growth signals, such as the PI3K/Akt pathway, thus leading to chemotherapy resistance in breast cancer [245]. By activation of TGF $\beta / \mathrm{Smad} 2$ signals and ECM, HA-HMMR conferred resistance to chemotherapy in gastric cancer [246]. Degrading HA or breaking down the interaction between HA and ECM molecules improved drug resistance and blocked cancer progression. Notably, HA depletion was shown to have very promising results in preclinical studies [247]. Because HYAL degrades HA, the activity and expression of HYAL can be adjusted as a choice to determine the concentration of HA in TME. Using HYAL to deplete HA leads NK cells to attach to a high HA matrix and significantly enhance trastuzumab or cetuximab-dependent cell-mediated cytotoxicity in breast cancer [248]. However, involvement in ECM remodeling leads HA to enhance the treatment effect. HA increased penetration by causing collagen degradation and further altering the dense extracellular space to looser space, thereby increasing the chemo-sensitivity 
in gallbladder cancer [249]. HA, as a material with special physiochemical properties, is now widely used as a promising tumor drug carrier; the application and prospects of HA for drug delivery has been reviewed in recent works [250,251]. Without controversy, HA plays a role in many aspects of cancer development. More studies are needed to research the control of the number and pattern of HA in the TME, to block the interaction between HA-related proteins and drug responses, all of which will bring great benefits to the cancer treatment.

As a tumor suppressor, lumican enhanced TIL and improved the ability of immune cells to eliminate tumors in several solid tumors [51]. By inhibiting tumor metastasis, adding exogenetic decorin inhibited the growth of prostate cancer [252]. However, most PGs contribute to malignancy by triggering therapeutic resistance; they could be the targets of cancer treatment. Through versican silencing, chemoresistance could be ameliorated, indicating that versican could be a potential therapeutic target in prostate cancer [253]. CSPG4-targeting, including immunotoxins and antibodies, improved therapeutic resistance by enhancing the effectiveness of photochemical internalization in breast cancer [254] and by inhibiting cell proliferation in melanoma patients [255]. To be more specific, PGs conferred resistance to tumor therapy by activating key signals such as activation of EGFR-AKT signaling by versican, inducing breast cancer self-renewal [256] and chemotherapy resistance [49], activating NF- $\mathrm{KB}$ signaling by biglycan to promote resistance to chemotherapy of colon cancer [43] and activating the EGFR pathway by syndecan-1 to lead to chemoresistance in colon cancer [257]. Circulating syndecan-1 contributed to chemotherapy resistance in prostate cancer [114]. For a more detailed presentation about the targeting of these molecules and the corresponding curative effect, the reader can read the recent comprehensive work presented in Reference [258].

As mentioned above, PGs/GAGs play important roles in tumor survival and therapeutic resistance, suggesting that PGs/GAGs can be attractive targets in cancer therapy. We propose that any changes in the ECM should be taken seriously, particularly those that may affect therapeutic effects. Therapies designed to combine targeting PGs/GAGs with anti-tumor therapy may be potential strategies, inhibiting tumor survival and improving patient outcome. For instance, targeting CD44 using HA-labeled nanoparticles overcame chemoresistance with a higher efficiency in an ovarian carcinoma PDX model [259].

\section{Conclusions and Perspectives}

The research regarding ECM remodeling has elucidated its role in cancer initiation and progression. Comprehensive understanding of the altered abundance, structure, localization of ECM components, and the interaction signals between cancer cells, stroma cells, and ECM may help us to find more valuable biomarkers in cancer diagnosis and prognosis as well as to develop effective potential therapies. Those studies about PGs, GAG chains, and PG/GAG-related enzymes and surface receptors have shown encouraging diagnostic and prognostic values in an impressive number of preclinical studies and experimental models. However, few examples for use of PGs or GAGs as biomarkers/targets in a clinical routine setting have been extensively used. Perhaps one reason is the complexity and diversity of PG/GAG structures, such that it is difficult to fully define their fragments in the local ECM of cancer patients. The other reason is that disruption of individual PGs or GAGs can influence their downstream cascades and other related-signaling functions, leading to disordered cross-interacting networks within the TME. Tumoral heterogeneity of ECM, including expression levels, distribution, and derived sources of PGs/GAGs, is another reason for the difficulty of applying therapies. It is still difficult to fully define the regulatory processes of PGs/GAGs through a variety of mechanisms in extremely dynamic remodeling of ECM. Therefore, finding molecular regulation rules of PGs/GAGs in complex networks as well as establishing appropriate models and developing research tools of PGs/GAGs will be essential to transform these findings into clinical applications for targeting PGs/GAGs in the future. For example, using a combination of cell biology, novel approaches in chemistry glycobiology, biomedical nanotechnology, single cell sequencing, and bioinformatics to visualize abundance, size, and location of PGs/GAGs in spatio-temporal states of specific cancer TME are the top priorities. Studying the mechanisms by which networks regulate PGs/GAGs and malignant 
cells and how they become deregulated in various cancer types, distinguishing beneficial or detrimental roles in cancer progression, and developing accuracy in fluid detection are all conducive to improving early diagnosis levels, preventing tumorigenesis, realizing precision medicine, suppressing cancer progression, and further improving patient survival.

Author Contributions: Conceptualization, J.W. and H.D.; illustrations, K.H.; writing-original draft preparation, J.W. and M.H.; writing-review and editing, S.L. and H.D. All authors have read and agreed to the published version of the manuscript.

Funding: This work was supported by the National Key R\&D Program of China (2018YFC0910201), the Key R\&D Program of Guangdong Province (2019B020226001), and the Science and the Technology Planning Project of Guangzhou (201704020176).

Conflicts of Interest: The authors declare no conflict of interest.

\section{Abbreviations}

$\begin{array}{ll}\text { PGs } & \text { Proteoglycans } \\ \text { GAGs } & \text { Glycosaminoglycans } \\ \text { ECM } & \text { Extracellular matrix } \\ \text { CS } & \text { Chondroitin sulfate } \\ \text { DS } & \text { Dermatan sulfate } \\ \text { KS } & \text { Keratan sulfate } \\ \text { HS } & \text { Heparan sulfate } \\ \text { HA } & \text { Hyaluronic acid } \\ \text { EGFR } & \text { Epidermal growth factor receptor } \\ \text { HGFR } & \text { Hepatocyte growth factor receptor } \\ \text { IGFR } & \text { Insulin-like growth factor 1 receptor } \\ \text { HGF } & \text { Hepatocyte growth factor } \\ \text { HMMR } & \text { HA-mediated motility receptor } \\ \text { LYVE-1 } & \text { Lymphatic vessel endothelial hyaluronic receptor-1 } \\ \text { EMMPRIN } & \text { Extracellular matrix metalloproteinase inducer } \\ \text { RTKs } & \text { Receptor tyrosine kinases } \\ \text { TLR } & \text { Toll like receptor }\end{array}$

\section{References}

1. Park, J.S.; Burckhardt, C.J.; Lazcano, R.; Solis, L.M.; Isogai, T.; Li, L.; Chen, C.S.; Gao, B.; Minna, J.D.; Bachoo, R.; et al. Mechanical regulation of glycolysis via cytoskeleton architecture. Nature 2020, 578, 621-626. [CrossRef] [PubMed]

2. Levental, K.R.; Yu, H.; Kass, L.; Lakins, J.N.; Egeblad, M.; Erler, J.; Fong, S.F.; Csiszar, K.; Giaccia, A.; Weninger, W.; et al. Matrix Crosslinking Forces Tumor Progression by Enhancing Integrin Signaling. Cell 2009, 139, 891-906. [CrossRef] [PubMed]

3. Özdemir, B.C.; Pentcheva-Hoang, T.; Carstens, J.L.; Zheng, X.; Wu, C.-C.; Simpson, T.R.; Laklai, H.; Sugimoto, H.; Kahlert, C.; Novitskiy, S.V.; et al. Depletion of Carcinoma-Associated Fibroblasts and Fibrosis Induces Immunosuppression and Accelerates Pancreas Cancer with Reduced Survival. Cancer Cell 2015, 28, 831-833. [CrossRef] [PubMed]

4. De Palma, M.; Biziato, D.; Petrova, T.V. Microenvironmental regulation of tumour angiogenesis. Nat. Rev. Cancer 2017, 17, 457-474. [CrossRef] [PubMed]

5. Mongiat, M.; Andreuzzi, E.; Tarticchio, G.; Paulitti, A. Extracellular Matrix, a Hard Player in Angiogenesis. Int. J. Mol. Sci. 2016, 17, 1822. [CrossRef] [PubMed]

6. Ahmadzadeh, H.; Webster, M.R.; Behera, R.; Valencia, A.M.J.; Wirtz, D.; Weeraratna, A.T.; Shenoy, V.B. Modeling the two-way feedback between contractility and matrix realignment reveals a nonlinear mode of cancer cell invasion. Proc. Natl. Acad. Sci. USA 2017, 114, E1617-E1626. [CrossRef] [PubMed]

7. Kaur, A.; Ecker, B.L.; Douglass, S.M.; Kugel, C.H.; Webster, M.R.; Almeida, F.V.; Somasundaram, R.; Hayden, J.; Ban, E.; Ahmadzadeh, H.; et al. Remodeling of the Collagen Matrix in Aging Skin Promotes Melanoma Metastasis and Affects Immune Cell Motility. Cancer Discov. 2018, 9, 64-81. [CrossRef] 
8. Shaked, Y. The pro-tumorigenic host response to cancer therapies. Nat. Rev. Cancer 2019, 19, 667-685. [CrossRef]

9. Yuzhalin, A.E.; Urbonas, T.; Silva, M.A.; Muschel, R.J.; Gordon-Weeks, A.N. A core matrisome gene signature predicts cancer outcome. Br. J. Cancer 2018, 118, 435-440. [CrossRef]

10. Wei, S.C.; Fattet, L.; Tsai, J.H.; Guo, Y.; Pai, V.H.; Majeski, H.E.; Chen, A.C.; Sah, R.L.; Taylor, S.S.; Engler, A.J.; et al. Matrix stiffness drives epithelial-mesenchymal transition and tumour metastasis through a TWIST1-G3BP2 mechanotransduction pathway. Nat. Cell Biol. 2015, 17, 678-688. [CrossRef]

11. Henriet, P.; Zhong, Z.-D.; Brooks, P.C.; Weinberg, K.I.; Declerck, Y.A. Contact with fibrillar collagen inhibits melanoma cell proliferation by up-regulating p27KIP1. Proc. Natl. Acad. Sci. USA 2000, 97, 10026-10031. [CrossRef] [PubMed]

12. Mouw, J.K.; Ou, G.; Weaver, V.M. Extracellular matrix assembly: A multiscale deconstruction. Nat. Rev. Mol. Cell Biol. 2014, 15, 771-785. [CrossRef] [PubMed]

13. Baghy, K.; Tátrai, P.; Regős, E.; Kovalszky, I. Proteoglycans in liver cancer. World J. Gastroenterol. 2016, 22, 379-393. [CrossRef] [PubMed]

14. Cui, H.; Freeman, C.; Jacobson, G.A.; Small, D.H. Proteoglycans in the central nervous system: Role in development, neural repair, and Alzheimer's disease. IUBMB Life 2013, 65, 108-120. [CrossRef] [PubMed]

15. Edwards, I.J. Proteoglycans in prostate cancer. Nat. Rev. Urol. 2012, 9, 196-206. [CrossRef] [PubMed]

16. Shi, Y.; Wei, J.; Chen, Z.; Yuan, Y.; Li, X.; Zhang, Y.; Meng, Y.; Hu, Y.; Du, H. Integrative Analysis Reveals Comprehensive Altered Metabolic Genes Linking with Tumor Epigenetics Modification in Pan-Cancer. BioMed Res. Int. 2019, 2019, 6706354. [CrossRef]

17. Chanmee, T.; Ontong, P.; Itano, N. Hyaluronan: A modulator of the tumor microenvironment. Cancer Lett. 2016, 375, 20-30. [CrossRef]

18. Rabelink, T.J.; van der Berg, B.M.; Garsen, M.; Wang, G.; Elkin, M.; van der Vlag, J. Heparanase: Roles in cell survival, extracellular matrix remodelling and the development of kidney disease. Nat. Rev. Nephrol. 2017, 13, 201-212. [CrossRef]

19. Hunter, K.E.; Palermo, C.; Kester, J.C.; Simpson, K.; Li, J.-P.; Tang, L.H.; Klimstra, D.S.; Vlodavsky, I.; Joyce, J.A. Heparanase promotes lymphangiogenesis and tumor invasion in pancreatic neuroendocrine tumors. Oncogene 2013, 33, 1799-1808. [CrossRef]

20. Kadenhe-Chiweshe, A.; Papa, J.; McCrudden, K.W.; Frischer, J.; Bae, J.-O.; Huang, J.; Lefkowitch, J.H.; Feirt, N.; Rudge, J.; Holash, J.; et al. Sustained VEGF Blockade Results in Microenvironmental Sequestration of VEGF by Tumors and Persistent VEGF Receptor-2 Activation. Mol. Cancer Res. 2008, 6, 1-9. [CrossRef]

21. Xu, D.; Esko, J.D. Demystifying Heparan Sulfate-Protein Interactions. Annu. Rev. Biochem. 2014, 83, $129-157$. [CrossRef] [PubMed]

22. Tan, J.-X.; Wang, X.-Y.; Li, H.-Y.; Su, X.-L.; Wang, L.; Ran, L.; Zheng, K.; Ren, G.-S. HYAL1 overexpression is correlated with the malignant behavior of human breast cancer. Int. J. Cancer 2011, 128, 1303-1315. [CrossRef] [PubMed]

23. Udabage, L.; Brownlee, G.R.; Nilsson, S.K.; Brown, T.J.; Nilsson, S.K. The over-expression of HAS2, Hyal-2 and CD44 is implicated in the invasiveness of breast cancer. Exp. Cell Res. 2005, 310, 205-217. [CrossRef] [PubMed]

24. Guan, X.; Chen, J.; Hu, Y.; Lin, L.; Sun, P.; Tian, H.; Chen, X. Highly enhanced cancer immunotherapy by combining nanovaccine with hyaluronidase. Biomaterials 2018, 171, 198-206. [CrossRef] [PubMed]

25. Hadler-Olsen, E.; Winberg, J.-O.; Uhlin-Hansen, L. Matrix metalloproteinases in cancer: Their value as diagnostic and prognostic markers and therapeutic targets. Tumor Biol. 2013, 34, 2041-2051. [CrossRef] [PubMed]

26. Kessenbrock, K.; Plaks, V.; Werb, Z. Matrix metalloproteinases: Regulators of the tumor microenvironment. Cell 2010, 141, 52-67. [CrossRef]

27. Xu, J.; Yu, Y.; He, X.; Niu, N.; Li, X.; Zhang, R.; Hu, J.; Ma, J.; Yu, X.; Sun, Y.; et al. Tumor-associated macrophages induce invasion and poor prognosis in human gastric cancer in a cyclooxygenase-2/MMP9-dependent manner. Am. J. Transl. Res. 2019, 11, 6040-6054.

28. Park, J.-H.; Rasch, M.G.; Qiu, J.; Lund, I.K.; Egeblad, M. Presence of insulin-like growth factor binding proteins correlates with tumor-promoting effects of matrix metalloproteinase 9 in breast cancer. Neoplasia 2015, 17, 421-433. [CrossRef]

29. Cathcart, J.M.; Cao, J. MMP Inhibitors: Past, present and future. Front. Biosci. 2015, 20, 1164-1178. 
30. Riegler, J.; Labyed, Y.; Rosenzweig, S.; Javinal, V.; Castiglioni, A.; Dominguez, C.X.; Long, J.E.; Li, Q.; Sandoval, W.; Junttila, M.R.; et al. Tumor Elastography and Its Association with Collagen and the Tumor Microenvironment. Clin. Cancer Res. 2018, 24, 4455-4467. [CrossRef]

31. Tu, H.; Sasaki, T.; Snellman, A.; Göhring, W.; Pirilä, P.; Timpl, R.; Pihlajaniemi, T. The Type XIII Collagen Ectodomain Is a 150-nm Rod and Capable of Binding to Fibronectin, Nidogen-2, Perlecan, and Heparin. J. Biol. Chem. 2002, 277, 23092-23099. [CrossRef] [PubMed]

32. Koivunen, J.; Kemppainen, A.V.; Finnilä, M.A.; Keski-Filppula, R.; Härönen, H.; Tu, H.; Pellikka, H.; Heikkinen, A.; Kylmäoja, E.; Sormunen, R.; et al. Collagen XIII-derived ectodomain regulates bone angiogenesis and intracortical remodeling. Matrix Biol. 2019, 83, 6-25. [CrossRef] [PubMed]

33. Zhang, Y.; Zou, X.; Qian, W.; Weng, X.; Zhang, L.; Zhang, L.; Wang, S.; Cao, X.; Ma, L.; Wei, G.; et al. Enhanced PAPSS2/VCAN sulfation axis is essential for Snail-mediated breast cancer cell migration and metastasis. Cell Death Differ. 2019, 26, 565-579. [CrossRef] [PubMed]

34. Salem, M.; O’Brien, J.A.; Bernaudo, S.; Shawer, H.; Ye, G.; Brkić, J.; Amleh, A.; Vanderhyden, B.C.; Refky, B.; Yang, B.B.; et al. miR-590-3p Promotes Ovarian Cancer Growth and Metastasis via a Novel FOXA2-Versican Pathway. Cancer Res. 2018, 78, 4175-4190. [CrossRef] [PubMed]

35. Gorter, A.; Zijlmans, H.J.; van Gent, H.; Trimbos, J.B.; Fleuren, G.J.; Jordanova, E.S. Versican expression is associated with tumor-infiltrating CD8-positive T cells and infiltration depth in cervical cancer. Mod. Pathol. 2010, 23, 1605-1615. [CrossRef]

36. Yeung, T.-L.; Leung, C.S.; Wong, K.-K.; Samimi, G.; Thompson, M.S.; Liu, J.; Zaid, T.M.; Ghosh, S.; Birrer, M.J.; Mok, S.C. TGF- $\beta$ modulates ovarian cancer invasion by upregulating CAF-derived versican in the tumor microenvironment. Cancer Res. 2013, 73, 5016-5028. [CrossRef]

37. Su, Z.; Kishida, S.; Tsubota, S.; Sakamoto, K.; Cao, D.; Kiyonari, S.; Ohira, M.; Kamijo, T.; Narita, A.; Xu, Y.; et al. Neurocan, an extracellular chondroitin sulfate proteoglycan, stimulates neuroblastoma cells to promote malignant phenotypes. Oncotarget 2017, 8, 106296-106310. [CrossRef]

38. Lu, R.; Wu, C.; Guo, L.; Liu, Y.; Mo, W.; Wang, H.; Ding, J.; Wong, E.T.; Yu, M. The role of brevican in glioma: Promoting tumor cell motility in vitro and in vivo. BMC Cancer 2012, 12, 607. [CrossRef]

39. Nutt, C.L.; Zerillo, C.A.; Kelly, G.M.; Hockfield, S. Brain enriched hyaluronan binding (BEHAB)/brevican increases aggressiveness of CNS-1 gliomas in Lewis rats. Cancer Res. 2001, 61, 7056-7059.

40. Sun, H.; Wang, X.; Zhang, Y.; Che, X.; Liu, Z.; Zhang, L.; Qiu, C.; Lv, Q.; Jiang, J. Biglycan enhances the ability of migration and invasion in endometrial cancer. Arch. Gynecol. Obstet. 2016, 293, 429-438. [CrossRef]

41. Schulz, G.B.; Grimm, T.; Sers, C.; Riemer, P.; Elmasry, M.; Kirchner, T.; Stief, C.G.; Karl, A.; Horst, D. Prognostic value and association with epithelial-mesenchymal transition and molecular subtypes of the proteoglycan biglycan in advanced bladder cancer. Urol. Oncol. Semin. Orig. Investig. 2019, 37, 530.e9-530.e18. [CrossRef] [PubMed]

42. Andrlova, H.; Mastroianni, J.; Madl, J.; Kern, J.S.; Melchinger, W.; Dierbach, H.; Wernet, F.; Follo, M.; Technau-Hafsi, K.; Has, C.; et al. Biglycan expression in the melanoma microenvironment promotes invasiveness via increased tissue stiffness inducing integrin- $\beta 1$ expression. Oncotarget 2017, 8, 42901-42916. [CrossRef] [PubMed]

43. Liu, B.; Xu, T.; Xu, X.; Cui, Y.; Xing, X. Biglycan promotes the chemotherapy resistance of colon cancer by activating NF-кB signal transduction. Mol. Cell. Biochem. 2018, 449, 285-294. [CrossRef] [PubMed]

44. Xing, X.; Gu, X.; Ma, T.; Ye, H. Biglycan up-regulated vascular endothelial growth factor (VEGF) expression and promoted angiogenesis in colon cancer. Tumor Biol. 2015, 36, 1773-1780. [CrossRef]

45. Hu, L.; Duan, Y.-T.; Li, J.-F.; Su, L.-P.; Yan, M.; Zhu, Z.-G.; Liu, B.; Yang, Q.-M. Biglycan enhances gastric cancer invasion by activating FAK signaling pathway. Oncotarget 2014, 5, 1885-1896. [CrossRef]

46. Bi, X.; Pohl, N.M.; Qian, Z.; Yang, G.R.; Gou, Y.; Guzman, G.; Kajdacsy-Balla, A.; Iozzo, R.V.; Yang, W. Decorin-mediated inhibition of colorectal cancer growth and migration is associated with E-cadherin in vitro and in mice. Carcinogenesis 2011, 33, 326-330. [CrossRef]

47. Merline, R.; Moreth, K.; Beckmann, J.; Nastase, M.V.; Zeng-Brouwers, J.; Tralhão, J.G.; LeMarchand, P.; Pfeilschifter, J.; Schaefer, R.M.; Iozzo, R.V.; et al. Signaling by the Matrix Proteoglycan Decorin Controls Inflammation and Cancer Through PDCD4 and MicroRNA-21. Sci. Signal. 2011, 4, ra75. [CrossRef]

48. Gao, Y.; Ma, H.-Y.; Xu, Q.-Y.; Li, Y.; Zhang, S.-L.; Qu, Y.-Y.; Zhang, Y.; Yin, H. Mechanism of decorin protein inhibiting invasion and metastasis of non-small cell lung cancer. Eur. Rev. Med. Pharmacol. Sci. 2019, 23, $1520-1527$. 
49. Li, X.; Roife, D.; Kang, Y.; Dai, B.; Pratt, M.; Fleming, J.B. Extracellular lumican augments cytotoxicity of chemotherapy in pancreatic ductal adenocarcinoma cells via autophagy inhibition. Oncogene 2016, 35, 4881-4890. [CrossRef]

50. Li, X.; Kang, Y.; Roife, D.; Lee, Y.; Pratt, M.; Perez, M.R.; Dai, B.; Koay, E.J.; Fleming, J.B. Prolonged exposure to extracellular lumican restrains pancreatic adenocarcinoma growth. Oncogene 2017, 36, 5432-5438. [CrossRef]

51. Momin, N.; Mehta, N.K.; Bennett, N.R.; Ma, L.; Palmeri, J.R.; Chinn, M.M.; Lutz, E.A.; Kang, B.H.; Irvine, D.J.; Spranger, S.; et al. Anchoring of intratumorally administered cytokines to collagen safely potentiates systemic cancer immunotherapy. Sci. Transl. Med. 2019, 11, eaaw2614. [CrossRef] [PubMed]

52. Li, X.; Lee, Y.; Kang, Y.; Dai, B.; Perez, M.R.; Pratt, M.; Koay, E.; Kim, M.; Brekken, R.A.; Fleming, J.B. Hypoxia-induced autophagy of stellate cells inhibits expression and secretion of lumican into microenvironment of pancreatic ductal adenocarcinoma. Cell Death Differ. 2018, 26, 382-393. [CrossRef] [PubMed]

53. Yang, C.-T.; Li, J.-M.; Chu, W.-K.; Chow, S.-E. Downregulation of lumican accelerates lung cancer cell invasion through p120 catenin. Cell Death Dis. 2018, 9, 414. [CrossRef] [PubMed]

54. Hsiao, K.-C.; Chu, P.-Y.; Chang, G.-C.; Liu, K.-J. Elevated Expression of Lumican in Lung Cancer Cells Promotes Bone Metastasis through an Autocrine Regulatory Mechanism. Cancers 2020, 12, 233. [CrossRef] [PubMed]

55. Oldberg, Å.; Kalamajski, S.; Salnikov, A.V.; Stuhr, L.; Mörgelin, M.; Reed, R.K.; Heldin, N.-E.; Rubin, K. Collagen-binding proteoglycan fibromodulin can determine stroma matrix structure and fluid balance in experimental carcinoma. Proc. Natl. Acad. Sci. USA 2007, 104, 13966-13971. [CrossRef] [PubMed]

56. Mondal, B.; Patil, V.; Shwetha, S.D.; Sravani, K.; Hegde, A.S.; Arivazhagan, A.; Santosh, V.; Kanduri, M.; Somasundaram, K. Integrative functional genomic analysis identifies epigenetically regulated fibromodulin as an essential gene for glioma cell migration. Oncogene 2016, 36, 71-83. [CrossRef]

57. Franses, J.W.; Baker, A.B.; Chitalia, V.; Edelman, E.R. Stromal Endothelial Cells Directly Influence Cancer Progression. Sci. Transl. Med. 2011, 3, 66ra5. [CrossRef]

58. Grindel, B.J.; Martinez, J.R.; Tellman, T.; Harrington, D.A.; Zafar, H.; Nakhleh, L.; Chung, L.W.; Farach-Carson, M.C. Matrilysin/MMP-7 Cleavage of Perlecan/HSPG2 Complexed with Semaphorin 3A Supports FAK-Mediated Stromal Invasion by Prostate Cancer Cells. Sci. Rep. 2018, 8, 7262. [CrossRef]

59. Vennin, C.; Mélénec, P.; Rouet, R.; Nobis, M.; Cazet, A.S.; Murphy, K.J.; Herrmann, D.; Reed, D.A.; Lucas, M.C.; Warren, S.C.; et al. CAF hierarchy driven by pancreatic cancer cell p53-status creates a pro-metastatic and chemoresistant environment via perlecan. Nat. Commun. 2019, 10, 1-22. [CrossRef]

60. Njah, K.; Chakraborty, S.; Qiu, B.; Arumugam, S.; Raju, A.; Pobbati, A.V.; Lakshmanan, M.; Tergaonkar, V.; Thibault, G.; Wang, X.; et al. A Role of Agrin in Maintaining the Stability of Vascular Endothelial Growth Factor Receptor-2 during Tumor Angiogenesis. Cell Rep. 2019, 28, 949-965. [CrossRef]

61. Chakraborty, S.; Lakshmanan, M.; Swa, H.L.; Chen, J.; Zhang, X.; Ong, Y.S.; Loo, L.S.; Akıncilar, S.C.; Gunaratne, J.; Tergaonkar, V.; et al. An oncogenic role of Agrin in regulating focal adhesion integrity in hepatocellular carcinoma. Nat. Commun. 2015, 6, 6184. [CrossRef] [PubMed]

62. Yao, W.; Rose, J.; Wang, W.; Seth, S.; Jiang, H.; Taguchi, A.; Liu, J.; Yan, L.; Kapoor, A.; Hou, P.; et al. Syndecan 1 is a critical mediator of macropinocytosis in pancreatic cancer. Nature 2019, 568, 410-414. [CrossRef] [PubMed]

63. Ibrahim, S.A.; Gadalla, R.; El-Ghonaimy, E.A.; Samir, O.; Mohamed,H.T.; Hassan, H.; Greve, B.; El-Shinawi, M.; Mohamed, M.M.; Götte, M. Syndecan-1 is a novel molecular marker for triple negative inflammatory breast cancer and modulates the cancer stem cell phenotype via the IL-6/STAT3, Notch and EGFR signaling pathways. Mol. Cancer 2017, 16, 57. [CrossRef] [PubMed]

64. Aikawa, T.; Whipple, C.A.; Lopez, M.E.; Gunn, J.; Young, A.; Lander, A.D.; Korc, M. Glypican-1 modulates the angiogenic and metastatic potential of human and mouse cancer cells. J. Clin. Investig. 2008, 118, 89-99. [CrossRef]

65. Matsuzaki, S.; Serada, S.; Hiramatsu, K.; Nojima, S.; Matsuzaki, S.; Ueda, Y.; Ohkawara, T.; Mabuchi, S.; Fujimoto, M.; Morii, E.; et al. Anti-glypican-1 antibody-drug conjugate exhibits potent preclinical antitumor activity against glypican-1 positive uterine cervical cancer. Int. J. Cancer 2018, 142, 1056-1066. [CrossRef]

66. Li, N.; Wei, L.; Liu, X.; Bai, H.; Ye, Y.; Li, D.; Li, N.; Baxa, U.; Wang, Q.; Lv, L.; et al. A Frizzled-Like Cysteine-Rich Domain in Glypican-3 Mediates Wnt Binding and Regulates Hepatocellular Carcinoma Tumor Growth in Mice. Hepatology 2019, 70, 1231-1245. [CrossRef] 
67. Yuan, S.; Yu, Z.; Liu, Q.; Zhang, M.; Xiang, Y.; Wu, N.; Wu, L.; Hu, Z.; Xu, B.; Cai, T.; et al. GPC5, a novel epigenetically silenced tumor suppressor, inhibits tumor growth by suppressing $\mathrm{Wnt} / \beta$-catenin signaling in lung adenocarcinoma. Oncogene 2016, 35, 6120-6131. [CrossRef]

68. Yang, X.; Zhang, Z.; Qiu, M.; Hu, J.; Fan, X.; Wang, J.; Xu, L.; Yin, R. Glypican-5 is a novel metastasis suppressor gene in non-small cell lung cancer. Cancer Lett. 2013, 341, 265-273. [CrossRef]

69. Guo, J.-Y.; Hsu, H.-S.; Tyan, S.-W.; Li, F.-Y.; Shew, J.-Y.; Lee, W.-H.; Chen, J.-Y. Serglycin in tumor microenvironment promotes non-small cell lung cancer aggressiveness in a CD44-dependent manner. Oncogene 2017, 36, 2457-2471. [CrossRef]

70. Li, X.-J.; Ong, C.K.; Cao, Y.; Xiang, Y.-Q.; Shao, J.-Y.; Ooi, A.; Peng, L.-X.; Lu, W.-H.; Zhang, Z.; Petillo, D.; et al. Serglycin Is a Theranostic Target in Nasopharyngeal Carcinoma that Promotes Metastasis. Cancer Res. 2011, 71, 3162-3172. [CrossRef]

71. Bouris, P.; Manou, D.; Sopaki-Valalaki, A.; Kolokotroni, A.; Moustakas, A.; Kapoor, A.; Iozzo, R.V.; Karamanos, N.K.; Theocharis, A.D. Serglycin promotes breast cancer cell aggressiveness: Induction of epithelial to mesenchymal transition, proteolytic activity and IL-8 signaling. Matrix Biol. 2018, 74, 35-51. [CrossRef] [PubMed]

72. Mitsui, Y.; Shiina, H.; Kato, T.; Maekawa, S.; Hashimoto, Y.; Shiina, M.; Imai-Sumida, M.; Kulkarni, P.; Dasgupta, P.; Wong, R.K.; et al. Versican Promotes Tumor Progression, Metastasis and Predicts Poor Prognosis in Renal Carcinoma. Mol. Cancer Res. 2017, 15, 884-895. [CrossRef] [PubMed]

73. Long, X.; Deng, Z.; Li, G.; Wang, Z. Identification of critical genes to predict recurrence and death in colon cancer: Integrating gene expression and bioinformatics analysis. Cancer Cell Int. 2018, 18, 139. [CrossRef] [PubMed]

74. Chida, S.; Okayama, H.; Noda, M.; Saito, K.; Nakajima, T.; Aoto, K.; Hayase, S.; Momma, T.; Ohki, S.; Kono, K.; et al. Stromal VCAN expression as a potential prognostic biomarker for disease recurrence in stage II-III colon cancer. Carcinogenesis 2016, 37, 878-887. [CrossRef] [PubMed]

75. Kulbe, H.; Otto, R.; Darb-Esfahani, S.; Lammert, H.; Abobaker, S.; Welsch, G.; Chekerov, R.; Schäfer, R.; Dragun, D.; Hummel, M.; et al. Discovery and Validation of Novel Biomarkers for Detection of Epithelial Ovarian Cancer. Cells 2019, 8, 713. [CrossRef] [PubMed]

76. Gupta, N.; Kumar, R.; Seth, T.; Garg, B.; Sati, H.C.; Sharma, A. Clinical significance of circulatory microRNA-203 in serum as novel potential diagnostic marker for multiple myeloma. J. Cancer Res. Clin. Oncol. 2019, 145, 1601-1611. [CrossRef]

77. Setoguchi, T.; Kamiya, K.; Tanaka, T.; Baba, S.; Sasaki, T.; Konno, H.; Goto-Inoue, N.; Kikuchi, H.; Yamamoto, M.; Baba, M.; et al. Microarray analysis identifies versican and CD9 as potent prognostic markers in gastric gastrointestinal stromal tumors. Cancer Sci. 2011, 102, 883-889. [CrossRef]

78. Jiang, K.; Liu, H.; Xie, D.; Xiao, Q. Differentially expressed genes ASPN, COL1A1, FN1, VCAN and MUC5AC are potential prognostic biomarkers for gastric cancer. Oncol. Lett. 2019, 17, 3191-3202. [CrossRef]

79. Pirinen, R.; Leinonen, T.; Böhm, J.; Johansson, R.; Ropponen, K.; Kumpulainen, E.; Kosma, V.-M. Versican in nonsmall cell lung cancer: Relation to hyaluronan, clinicopathologic factors, and prognosis. Hum. Pathol. 2005, 36, 44-50. [CrossRef]

80. Rangel, M.P.; de Sá, V.K.; Prieto, T.G.; Martins, J.R.M.; Olivieri, E.R.; Carraro, D.; Takagaki, T.Y.; Capelozzi, V.L. Biomolecular analysis of matrix proteoglycans as biomarkers in non small cell lung cancer. Glycoconj. J. 2018, 35, 233-242. [CrossRef]

81. Naboulsi, W.; Megger, D.A.; Bracht, T.; Kohl, M.; Turewicz, M.; Eisenacher, M.; Voss, D.M.; Schlaak, J.F.; Hoffmann, A.-C.; Weber, F.; et al. Quantitative Tissue Proteomics Analysis Reveals Versican as Potential Biomarker for Early-Stage Hepatocellular Carcinoma. J. Proteome Res. 2016, 15, 38-47. [CrossRef] [PubMed]

82. Pukkila, M.; Kosunen, A.; Ropponen, K.; Virtaniemi, J.; Kellokoski, J.; Kumpulainen, E.; Pirinen, R.; Nuutinen, J.; Johansson, R.; Kosma, V. High stromal versican expression predicts unfavourable outcome in oral squamous cell carcinoma. J. Clin. Pathol. 2007, 60, 267-272. [CrossRef] [PubMed]

83. Ricciardelli, C.; Brooks, J.H.; Suwiwat, S.; Sakko, A.J.; Mayne, K.; Raymond, W.A.; Seshadri, R.; LeBaron, R.G.; Horsfall, D.J. Regulation of stromal versican expression by breast cancer cells and importance to relapse-free survival in patients with node-negative primary breast cancer. Clin. Cancer Res. 2002, 8, 1054-1060.

84. Suwiwat, S. Expression of Extracellular Matrix Components Versican, Chondroitin Sulfate, Tenascin, and Hyaluronan, and Their Association with Disease Outcome in Node-Negative Breast Cancer. Clin. Cancer Res. 2004, 10, 2491-2498. [CrossRef] [PubMed] 
85. Ghosh, S.; Albitar, L.; LeBaron, R.G.; Welch, W.R.; Samimi, G.; Birrer, M.J.; Berkowitz, R.S.; Mok, S.C. Up-regulation of stromal versican expression in advanced stage serous ovarian cancer. Gynecol. Oncol. 2010, 119, 114-120. [CrossRef] [PubMed]

86. Kodama, J.; Kusumoto, T.; Seki, N.; Nakamura, K.; Hongo, A.; Hiramatsu, Y.; Kodama, N. Clinical significance of syndecan-1 and versican expression in human epithelial ovarian cancer. Oncol. Rep. 2010, 23, 917-925. [CrossRef] [PubMed]

87. Kodama, J.; Hasengaowa Kusumoto, T.; Seki, N.; Matsuo, T.; Ojima, Y.; Nakamura, K.; Hongo, A.; Hiramatsu, Y. Prognostic significance of stromal versican expression in human endometrial cancer. Ann. Oncol. 2007, 18, 269-274. [CrossRef] [PubMed]

88. Ricciardelli, C.; Mayne, K.; Sykes, P.J.; Raymond, W.A.; McCaul, K.; Marshall, V.R.; Horsfall, D.J. Elevated levels of versican but not decorin predict disease progression in early-stage prostate cancer. Clin. Cancer Res. 1998, 4, 963-971.

89. Jacobsen, F.; Kraft, J.; Schroeder, C.; Hube-Magg, C.; Kluth, M.; Lang, D.S.; Simon, R.; Sauter, G.; Izbicki, J.R.; Clauditz, T.S.; et al. Up-regulation of Biglycan is Associated with Poor Prognosis and PTEN Deletion in Patients with Prostate Cancer. Neoplasia 2017, 19, 707-715. [CrossRef]

90. Yu, C.; Chen, J.; Ma, J.; Zang, L.; Dong, F.; Sun, J.; Zheng, M. Identification of Key Genes and Signaling Pathways Associated with the Progression of Gastric Cancer. Pathol. Oncol. Res. 2020, 26, 1903-1919. [CrossRef]

91. Qian, Z.; Zhang, G.; Song, G.; Shi, J.; Gong, L.; Mou, Y.; Han, Y. Integrated analysis of genes associated with poor prognosis of patients with colorectal cancer liver metastasis. Oncotarget 2017, 8, 25500-25512. [CrossRef] [PubMed]

92. Zaidi, A.H.; Gopalakrishnan, V.; Kasi, P.M.; Zeng, X.; Malhotra, U.; Balasubramanian, J.; Visweswaran, S.; Sun, M.; Flint, M.; Davison, J.M.; et al. Evaluation of a 4-protein serum biomarker panel-biglycan, annexin-A6, myeloperoxidase, and protein S100-A9 (B-AMP)-for the detection of esophageal adenocarcinoma. Cancer 2014, 120, 3902-3913. [CrossRef] [PubMed]

93. Zhu, Y.-H.; Yang, F.; Zhang, S.-S.; Zeng, T.-T.; Xie, X.; Guan, X.-Y. High expression of biglycan is associated with poor prognosis in patients with esophageal squamous cell carcinoma. Int. J. Clin. Exp. Pathol. 2013, 6, 2497-2505. [PubMed]

94. Liu, Y.; Li, W.; Li, X.; Tai, Y.; Lu, Q.; Yang, N.; Jiang, J. Expression and significance of biglycan in endometrial cancer. Arch. Gynecol. Obstet. 2014, 289, 649-655. [CrossRef]

95. Aprile, G.; Avellini, C.; Reni, M.; Mazzer, M.; Foltran, L.; Rossi, D.; Cereda, S.; Iaiza, E.; Fasola, G.; Piga, A. Biglycan expression and clinical outcome in patients with pancreatic adenocarcinoma. Tumor Biol. 2013, 34, 131-137. [CrossRef] [PubMed]

96. Falakian, Z.; Shahani, T.; Rezaie, R.; Mazloomzadeh, S.; Sirati, F.; Jalilvand, A.; Jahangiri, F.; Bahmani, P.; Jadali, F.; Atarian, S.; et al. Patients With Invasive Ductal Carcinoma Have Reduced Levels of Decorin Expression in Their Breast Tissue Compared to Patients With Fibroadenoma While Plasma Decorin Remains Unchanged. Arch. Iran. Med. 2018, 21, 509-517. [PubMed]

97. Jia, X.; Chen, C.; Chen, L.; Yu, C.; Kondo, T. Decorin as a prognostic biomarker in patients with malignant peripheral nerve sheath tumors. Oncol. Lett. 2019, 17, 3517-3522. [CrossRef]

98. Biaoxue, R.; Xiguang, C.; Hua, L.; Hui, M.; Yang, S.; Wei, Z.; Wenli, S.; Jie, D. Decreased expression of decorin and p57(KIP2) correlates with poor survival and lymphatic metastasis in lung cancer patients. Int. J. Biol. Markers 2011, 26, 9-21. [CrossRef]

99. Yan, Y.; Xu, Z.; Qian, L.; Zeng, S.; Zhou, Y.; Chen, X.; Wei, J.; Gong, Z. Identification of CAV1 and DCN as potential predictive biomarkers for lung adenocarcinoma. Am. J. Physiol. Cell. Mol. Physiol. 2019, 316, L630-L643. [CrossRef]

100. Kasamatsu, A.; Uzawa, K.; Minakawa, Y.; Ishige, S.; Kasama, H.; Endo-Sakamoto, Y.; Ogawara, K.; Shiiba, M.; Takiguchi, Y.; Tanzawa, H. Decorin in human oral cancer: A promising predictive biomarker of S-1 neoadjuvant chemosensitivity. Biochem. Biophys. Res. Commun. 2015, 457, 71-76. [CrossRef]

101. Wu, I.-C.; Wu, D.-C.; Huang, C.-C.; Lin, H.-S.; Chen, Y.-K.; Tsai, H.-J.; Lu, C.-Y.; Chou, S.-H.; Chou, Y.-P.; Li, L.-H.; et al. Plasma decorin predicts the presence of esophageal squamous cell carcinoma. Int. J. Cancer 2010, 127, 2138-2146. [CrossRef] [PubMed]

102. Troup, S.; Njue, C.; Kliewer, E.V.; Parisien, M.; Roskelley, C.; Chakravarti, S.; Roughley, P.J.; Murphy, L.C.; Watson, P.H. Reduced expression of the small leucine-rich proteoglycans, lumican, and decorin is associated with poor outcome in node-negative invasive breast cancer. Clin. Cancer Res. 2003, 9, 207-214. [PubMed] 
103. Cappellesso, R.; Millioni, R.; Arrigoni, G.; Simonato, F.; Caroccia, B.; Iori, E.; Guzzardo, V.; Ventura, L.; Tessari, P.; Fassina, A. Lumican Is Overexpressed in Lung Adenocarcinoma Pleural Effusions. PLoS ONE 2015, 10, e0126458. [CrossRef] [PubMed]

104. Li, X.; Truty, M.A.; Kang, Y.; Chopin-Laly, X.; Zhang, R.; Roife, D.J.; Chatterjee, D.; Lin, E.; Thomas, R.M.; Wang, H.; et al. Extracellular lumican inhibits pancreatic cancer cell growth and is associated with prolonged survival after surgery. Clin. Cancer Res. 2014, 20, 6529-6540. [CrossRef] [PubMed]

105. Seya, T.; Tanaka, N.; Shinji, S.; Yokoi, K.; Koizumi, M.; Teranishi, N.; Yamashita, K.; Tajiri, T.; Ishiwata, T.; Naito, Z. Lumican expression in advanced colorectal cancer with nodal metastasis correlates with poor prognosis. Oncol. Rep. 2006, 16, 1225-1230. [CrossRef] [PubMed]

106. Matsuda, Y.; Yamamoto, T.; Kudo, M.; Kawahara, K.; Kawamoto, M.; Nakajima, Y.; Koizumi, K.; Nakazawa, N.; Ishiwata, T.; Naito, Z. Expression and roles of lumican in lung adenocarcinoma and squamous cell carcinoma. Int. J. Oncol. 2008, 33, 1177-1185.

107. Ma, X.-L.; Shang, F.; Ni, W.; Zhu, J.; Luo, B.; Zhang, Y.-Q. Increased HSPG2 expression independently predicts poor survival in patients with oligoastrocytoma and oligodendroglioma. Eur. Rev. Med. Pharmacol. Sci. 2018, $22,6853-6863$.

108. Rivera, C.; Zandonadi, F.S.; Sánchez-Romero, C.; Soares, C.D.; Granato, D.C.; Gonzalez-Arriagada, W.A.; Leme, A.F.P. Agrin has a pathological role in the progression of oral cancer. Br. J. Cancer 2018, 118, 1628-1638. [CrossRef]

109. Li, D.; Gu, Q.; Xie, Z.; Shen, Q.; Li, H. Clinical significance of nuclear localisation of agrin in lung adenocarcinoma. Pol. J. Pathol. 2019, 70, 198-204. [CrossRef]

110. Hu, T.-H.; Huang, C.-C.; Wu, C.-L.; Lin, P.-R.; Liu, S.-Y.; Lin, J.-W.; Tai, M.H.; Chuang, J.-H. Increased endostatin/collagen XVIII expression correlates with elevated VEGF level and poor prognosis in hepatocellular carcinoma. Mod. Pathol. 2005, 18, 663-672. [CrossRef]

111. Chang, H.; Iizasa, T.; Shibuya, K.; Iyoda, A.; Suzuki, M.; Moriya, Y.; Liu, T.-L.; Hiwasa, T.; Hiroshima, K.; Fujisawa, T. Increased expression of collagen XVIII and its prognostic value in nonsmall cell lung carcinoma. Cancer 2004, 100, 1665-1672. [CrossRef] [PubMed]

112. Iizasa, T. Overexpression of Collagen XVIII Is Associated with Poor Outcome and Elevated Levels of Circulating Serum Endostatin in Non-Small Cell Lung Cancer. Clin. Cancer Res. 2004, 10, 5361-5366. [CrossRef] [PubMed]

113. Lee, K.S.; Park, G.S.; Hong, S.H.; Byun, J.H.; Woo, I.S.; Jeon, H.-M.; Hong, Y.S. Prognostic relevance of collagen XVIII expression in metastatic gastric carcinoma. Tumor Biol. 2010, 31, 165-170. [CrossRef] [PubMed]

114. Szarvas, T.; Sevcenco, S.; Módos, O.; Keresztes, D.; Nyirády, P.; Kubik, A.; Romics, M.; Kovalszky, I.; Reis, H.; Hadaschik, B.; et al. Circulating syndecan-1 is associated with chemotherapy-resistance in castration-resistant prostate cancer. Urol. Oncol. Semin. Orig. Investig. 2018, 36, 312.e9-312.e15. [CrossRef]

115. Campbell, D.H.; Lund, M.E.; Nocon, A.L.; Cozzi, P.J.; Frydenberg, M.; De Souza, P.; Schiller, B.; Beebe-Dimmer, J.L.; Ruterbusch, J.J.; Walsh, B. Detection of glypican-1 (GPC-1) expression in urine cell sediments in prostate cancer. PLoS ONE 2018, 13, e0196017. [CrossRef]

116. Zhou, C.-Y.; Dong, Y.-P.; Sun, X.; Sui, X.; Zhu, H.; Zhao, Y.-Q.; Zhang, Y.-Y.; Mason, C.; Zhu, Q.; Han, S. High levels of serum glypican-1 indicate poor prognosis in pancreatic ductal adenocarcinoma. Cancer Med. 2018, 7, 5525-5533. [CrossRef] [PubMed]

117. Lu, H.; Niu, F.; Liu, F.; Gao, J.; Sun, Y.; Zhao, X. Elevated glypican-1 expression is associated with an unfavorable prognosis in pancreatic ductal adenocarcinoma. Cancer Med. 2017, 6, 1181-1191. [CrossRef]

118. Duan, L.; Hu, X.-Q.; Feng, D.-Y.; Lei, S.-Y.; Hu, G.-H. GPC-1 may serve as a predictor of perineural invasion and a prognosticator of survival in pancreatic cancer. Asian J. Surg. 2013, 36, 7-12. [CrossRef]

119. Saito, T.; Sugiyama, K.; Hama, S.; Yamasaki, F.; Takayasu, T.; Nosaka, R.; Onishi, S.; Muragaki, Y.; Kawamata, T.; Kurisu, K. High Expression of Glypican-1 Predicts Dissemination and Poor Prognosis in Glioblastomas. World Neurosurg. 2017, 105, 282-288. [CrossRef]

120. Hara, H.; Takahashi, T.; Serada, S.; Fujimoto, M.; Ohkawara, T.; Nakatsuka, R.; Harada, E.; Nishigaki, T.; Takahashi, Y.; Nojima, S.; et al. Overexpression of glypican-1 implicates poor prognosis and their chemoresistance in oesophageal squamous cell carcinoma. Br. J. Cancer 2016, 115, 66-75. [CrossRef]

121. Liu, H.; Yang, C.; Lu, W.; Zeng, Y. Prognostic significance of glypican-3 expression in hepatocellular carcinoma: A meta-analysis. Medicine 2018, 97, e9702. [CrossRef] [PubMed] 
122. Hamaoka, M.; Kobayashi, T.; Tanaka, Y.; Mashima, H.; Ohdan, H. Clinical significance of glypican-3-positive circulating tumor cells of hepatocellular carcinoma patients: A prospective study. PLoS ONE 2019, 14, e0217586. [CrossRef] [PubMed]

123. Yao, H.; Yang, Z.; Liu, Z.; Miao, X.; Yang, L.; Li, D.; Zou, Q.; Yuan, Y. Glypican-3 and KRT19 are markers associating with metastasis and poor prognosis of pancreatic ductal adenocarcinoma. Cancer Biomark. 2016, 17, 397-404. [CrossRef] [PubMed]

124. Zhang, C.; Liu, Z.; Wang, L.; Qiao, B.; Du, E.; Li, L.; Xu, Y.; Zhang, Z. Prognostic significance of GPC5 expression in patients with prostate cancer. Tumor Biol. 2016, 37, 6413-6418. [CrossRef]

125. Chia, C.S.; Ong, W.S.; Li, X.; Soong, Y.L.; Chong, F.T.; Tan, H.-K.; Soo, K.-C.; Qian, C.-N.; Teh, B.T.; Iyer, N.G. Serglycin expression: An independent marker of distant metastases in nasopharyngeal carcinoma. Head Neck 2016, 38, 21-28. [CrossRef]

126. He, L.; Zhou, X.; Qu, C.; Tang, Y.; Zhang, Q.; Hong, J. Serglycin (SRGN) overexpression predicts poor prognosis in hepatocellular carcinoma patients. Med. Oncol. 2013, 30, 707. [CrossRef]

127. Gatto, F.; Blum, K.A.; Hosseini, S.S.; Ghanaat, M.; Kashan, M.; Maccari, F.; Galeotti, F.; Hsieh, J.J.; Volpi, N.; Hakimi, A.A.; et al. Plasma Glycosaminoglycans as Diagnostic and Prognostic Biomarkers in Surgically Treated Renal Cell Carcinoma. Eur. Urol. Oncol. 2018, 1, 364-377. [CrossRef]

128. Svensson, K.J.; Christianson, H.C.; Kucharzewska, P.; Fagerström, V.; Lundstedt, L.; Borgquist, S.; Jirström, K. Chondroitin sulfate expression predicts poor outcome in breast cancer. Int. J. Oncol. 2011, 39, 1421-1428. [CrossRef]

129. Van der Steen, S.C.; van Tilborg, A.A.; Vallen, M.J.; Bulten, J.; van Kuppevelt, T.H.; Massuger, L.F. Prognostic significance of highly sulfated chondroitin sulfates in ovarian cancer defined by the single chain antibody GD3A11. Gynecol. Oncol. 2016, 140, 527-536. [CrossRef]

130. Vallen, M.J.; Massuger, L.F.; Dam, G.B.T.; Bulten, J.; van Kuppevelt, T.H. Highly sulfated chondroitin sulfates, a novel class of prognostic biomarkers in ovarian cancer tissue. Gynecol. Oncol. 2012, 127, 202-209. [CrossRef]

131. Lo, S.-L.; Thike, A.A.; Tan, S.-Y.; Lim, T.K.-H.; Tan, I.B.-H.; Choo, S.-P.; Tan, P.-H.; Bay, B.-H.; Yip, G.W.-C. Expression of heparan sulfate in gastric carcinoma and its correlation with clinicopathological features and patient survival. J. Clin. Pathol. 2011, 64, 153-158. [CrossRef] [PubMed]

132. da Silva, M.; Mendes, A.; Martins, J.; Tobias-Machado, M.; Pinhal, M. Prospective evaluation of Chondroitin sulfate, Heparan sulfate and Hyaluronic acid in prostate cancer. Int. Braz. J. Urol. 2018, 44, 1139-1146. [CrossRef] [PubMed]

133. Peng, C.; Wallwiener, M.; Rudolph, A.; Cuk, K.; Eilber, U.; Celik, M.; Modugno, C.; Trumpp, A.; Heil, J.; Marmé, F.; et al. Plasma hyaluronic acid level as a prognostic and monitoring marker of metastatic breast cancer. Int. J. Cancer 2016, 138, 2499-2509. [CrossRef] [PubMed]

134. Anagnostopoulou, E.; Papanastasopoulou, C.; Papastamataki, M.; Kotsiou, A.; Topouzoglou, Z.; Anagnostopoulos, N.; Sitaras, N. Serum Hyaluronic Acid Levels Are Altered in Acute Leukemia Patients: Potential Prognostic Implications. Acta Haematol. 2017, 138, 44-51. [CrossRef] [PubMed]

135. Lokeshwar, V.B.; Obek, C.A.; Pham, H.T.; Wei, D.; Young, M.J.; Duncan, R.C.; Soloway, M.S.; Block, N.L. Urinary hyaluronic acid and hyaluronidase: Markers for bladder cancer detection and evaluation of grade. J. Urol. 2000, 163, 348-356. [CrossRef]

136. Aghcheli, K.; Parsian, H.; Qujeq, D.; Talebi, M.; Mousapour, A.; Pour, E.K.; Islami, F.; Semnani, S.; Malekzadeh, R. Serum hyaluronic acid and laminin as potential tumor markers for upper gastrointestinal cancers. Eur. J. Intern. Med. 2012, 23, 58-64. [CrossRef]

137. Llaneza, A.; Vizoso, F.; Rodriguez, J.C.; Raigoso, P.; Garcia-Muniz, J.L.; Allende, M.T.; Garcia-Moran, M. Hyaluronic acid as prognostic marker in resectable colorectal cancer. Br. J. Surg. 2000, 87, 1690-1696. [CrossRef]

138. Rangel, M.P.; de Sa, V.K.; Martins, V.; Martins, J.; Parra, E.; Mendes, A.; Andrade, P.; Reis, R.M.; Filho, A.L.; Oliveira, C.; et al. Tissue hyaluronan expression, as reflected in the sputum of lung cancer patients, is an indicator of malignancy. Braz. J. Med. Biol. Res. 2015, 48, 557-567. [CrossRef]

139. Creaney, J.; Dick, I.M.; Segal, A.; Musk, A.W.; Robinson, B.W. Pleural effusion hyaluronic acid as a prognostic marker in pleural malignant mesothelioma. Lung Cancer 2013, 82, 491-498. [CrossRef]

140. Mima, K.; Beppu, T.; Ishiko, T.; Chikamoto, A.; Nakagawa, S.; Hayashi, H.; Watanabè, M.; Sakamaki, K.; Baba, H. Preoperative serum hyaluronic acid level as a prognostic factor in patients undergoing hepatic resection for hepatocellular carcinoma. Br. J. Surg. 2014, 101, 269-276. [CrossRef] 
141. Ikuta, K.; Urakawa, H.; Kozawa, E.; Arai, E.; Zhuo, L.; Futamura, N.; Hamada, S.; Kimata, K.; Ishiguro, N.; Nishida, Y. Hyaluronan expression as a significant prognostic factor in patients with malignant peripheral nerve sheath tumors. Clin. Exp. Metastasis 2014, 31, 715-725. [CrossRef] [PubMed]

142. Correction: Heparanase Promotes Glioma Progression and Is Inversely Correlated with Patient Survival. Mol. Cancer Res. 2018, 16, 740-741. [CrossRef] [PubMed]

143. Tang, D.; Piao, Y.; Zhao, S.; Mu, X.; Li, S.; Ma, W.; Song, Y.; Wang, J.; Zhao, W.; Zhang, Q. Expression and correlation of matrix metalloproteinase- 9 and heparanase in patients with breast cancer. Med. Oncol. 2014, 31, 1-8. [CrossRef] [PubMed]

144. Zhang, W.; Chan, H.; Wei, L.; Pan, Z.; Zhang, J.; Li, L. Overexpression of heparanase in ovarian cancer and its clinical significance. Oncol. Rep. 2013, 30, 2279-2287. [CrossRef] [PubMed]

145. Wang, X.; Wen, W.; Wu, H.; Chen, Y.; Ren, G.; Guo, W. Heparanase expression correlates with poor survival in oral mucosal melanoma. Med. Oncol. 2013, 30, 633. [CrossRef]

146. Morera, D.S.; Hennig, M.S.; Talukder, A.; Lokeshwar, S.D.; Wang, J.; Garcia-Roig, M.; Ortiz, N.; Yates, T.J.; Lopez, L.E.; Kallifatidis, G.; et al. Hyaluronic acid family in bladder cancer: Potential prognostic biomarkers and therapeutic targets. Br. J. Cancer 2017, 117, 1507-1517. [CrossRef]

147. Kramer, M.W.; Golshani, R.; Merseburger, A.S.; Knapp, J.; Garcia, A.; Hennenlotter, J.; Duncan, R.C.; Soloway, M.S.; Jorda, M.; Kuczyk, M.A.; et al. HYAL-1 Hyaluronidase: A Potential Prognostic Indicator for Progression to Muscle Invasion and Recurrence in Bladder Cancer. Eur. Urol. 2010, 57, 86-94. [CrossRef]

148. Posey, J.T.; Soloway, M.S.; Ekici, S.; Sofer, M.; Civantos, F.; Duncan, R.C.; Lokeshwar, V.B. Evaluation of the prognostic potential of hyaluronic acid and hyaluronidase (HYAL1) for prostate cancer. Cancer Res. 2003, 63, 2638-2644.

149. Hautmann, S.H.; Schroeder, G.L.; Civantos, F.; Duncan, R.C.; Gnann, R.; Friedrich, M.G.; Hellstern, A.; Huland, H.; Soloway, M.S.; Lokeshwar, V.B. Hyaluronic acid and hyaluronidase. 2 new bladder carcinoma markers. Urol. Ausg. A 2001, 40,121-126. [CrossRef]

150. Bouga, H.; Tsouros, I.; Bounias, D.; Kyriakopoulou, D.; Stavropoulos, M.; Papageorgakopoulou, N.; Theocharis, D.A.; Vynios, D.H. Involvement of hyaluronidases in colorectal cancer. BMC Cancer 2010, 10, 499. [CrossRef]

151. Auvinen, P.; Rilla, K.; Tumelius, R.; Tammi, M.; Sironen, R.; Soini, Y.; Kosma, V.-M.; Mannermaa, A.; Viikari, J.; Tammi, R. Hyaluronan synthases (HAS1-3) in stromal and malignant cells correlate with breast cancer grade and predict patient survival. Breast Cancer Res. Treat. 2013, 143, 277-286. [CrossRef] [PubMed]

152. Yamada, Y.; Itano, N.; Narimatsu, H.; Kudo, T.; Morozumi, K.; Hirohashi, S.; Ochiai, A.; Ueda, M.; Kimata, K. Elevated transcript level of hyaluronan synthase1 gene correlates with poor prognosis of human colon cancer. Clin. Exp. Metastasis 2004, 21, 57-63. [CrossRef] [PubMed]

153. Josefsson, A.; Adamo, H.; Hammarsten, P.; Granfors, T.; Stattin, P.; Egevad, L.; Laurent, A.E.; Wikström, P.; Bergh, A. Prostate Cancer Increases Hyaluronan in Surrounding Nonmalignant Stroma, and This Response Is Associated with Tumor Growth and an Unfavorable Outcome. Am. J. Pathol. 2011, 179, 1961-1968. [CrossRef] [PubMed]

154. Deng, W.; Peng, W.; Wang, T.; Chen, J.; Zhu, S. Overexpression of MMPs Functions as a Prognostic Biomarker for Oral Cancer Patients: A Systematic Review and Meta-analysis. Oral Health Prev. Dent. 2019, 17, 505-514.

155. El-Sharkawi, F.; El Sabah, M.; Hassan, Z.; Khaled, H. The biochemical value of urinary metalloproteinases 3 and 9 in diagnosis and prognosis of bladder cancer in Egypt. J. Biomed. Sci. 2014, 21, 72. [CrossRef]

156. Cui, G.; Cai, F.; Ding, Z.; Gao, L. MMP14 predicts a poor prognosis in patients with colorectal cancer. Hum. Pathol. 2019, 83, 36-42. [CrossRef]

157. Cao, L.; Chen, C.; Zhu, H.; Gu, X.; Deng, D.; Tian, X.; Liu, J.; Xiao, Q. MMP16 is a marker of poor prognosis in gastric cancer promoting proliferation and invasion. Oncotarget 2016, 7, 51865-51874. [CrossRef]

158. Augustin, F.; Fiegl, M.; Schmid, T.; Pomme, G.; Sterlacci, W.; Tzankov, A. Receptor for hyaluronic acid-mediated motility (RHAMM, CD168) expression is prognostically important in both nodal negative and nodal positive large cell lung cancer. J. Clin. Pathol. 2015, 68, 368-373. [CrossRef]

159. Chi, A.; Shirodkar, S.P.; Escudero, D.O.; Ekwenna, O.O.; Yates, T.J.; Ayyathurai, R.; Garcia-Roig, M.; Gahan, J.C.; Manoharan, M.; Bird, V.G.; et al. Molecular characterization of kidney cancer: Association of hyaluronic acid family with histological subtypes and metastasis. Cancer 2012, 118, 2394-2402. [CrossRef]

160. Buttermore, S.T.; Hoffman, M.S.; Kumar, A.; Champeaux, A.; Nicosia, S.V.; Kruk, P. Increased RHAMM expression relates to ovarian cancer progression. J. Ovarian Res. 2017, 10, 66. [CrossRef] 
161. Zlobec, I.; Baker, K.; Terracciano, L.M.; Lugli, A. RHAMM, p21 Combined Phenotype Identifies Microsatellite Instability-High Colorectal Cancers with a Highly Adverse Prognosis. Clin. Cancer Res. 2008, 14, 3798-3806. [CrossRef] [PubMed]

162. Rein, D.T.; Roehrig, K.; Schöndorf, T.; Lazar, A.; Fleisch, M.; Niederacher, D.; Bender, H.G.; Dall, P. Expression of the hyaluronan receptor RHAMM in endometrial carcinomas suggests a role in tumour progression and metastasis. J. Cancer Res. Clin. Oncol. 2003, 129, 161-164. [CrossRef] [PubMed]

163. Giannopoulos, K.; Mertens, D.; Bühler, A.; Barth, T.F.; Idler, I.; Möller, P.; Kröber, A.; Greiner, J.; Chocholska, S.; Dmoszyñska, A.; et al. The candidate immunotherapeutical target, the receptor for hyaluronic acid-mediated motility, is associated with proliferation and shows prognostic value in B-cell chronic lymphocytic leukemia. Leukemia 2009, 23, 519-527. [CrossRef] [PubMed]

164. Maxwell, C.A.; Rasmussen, E.; Zhan, F.; Keats, J.J.; Adamia, S.; Strachan, E.; Crainie, M.; Walker, R.; Belch, A.R.; Pilarski, L.M.; et al. RHAMM expression and isoform balance predict aggressive disease and poor survival in multiple myeloma. Blood 2004, 104, 1151-1158. [CrossRef]

165. Kobayashi, K.; Matsumoto, H.; Matsuyama, H.; Fujii, N.; Inoue, R.; Yamamoto, Y.; Nagao, K. Clinical significance of CD44 variant 9 expression as a prognostic indicator in bladder cancer. Oncol. Rep. 2016, 36, 2852-2860. [CrossRef] [PubMed]

166. Weichert, W.; Schmitt, W.D.; Hauptmann, S. Epithelial hyaluronic acid and CD44v6 are mutually involved in invasion of colorectal adenocarcinomas and linked to patient prognosis. Virchows Arch. 2004, 445, 456-464. [CrossRef]

167. Go, S.-I.; Ko, G.H.; Lee, W.S.; Lee, J.-H.; Jeong, S.-H.; Lee, Y.-J.; Hong, S.C.; Ha, W.S. The Use of CD44 Variant 9 and Ki-67 Combination Can Predicts Prognosis Better Than Their Single Use in Early Gastric Cancer. Cancer Res. Treat. 2019, 51, 1411-1419. [CrossRef]

168. Go, S.-I.; Ko, G.H.; Lee, W.S.; Kim, R.B.; Lee, J.-H.; Jeong, S.-H.; Lee, Y.-J.; Hong, S.C.; Ha, W.S. CD44 Variant 9 Serves as a Poor Prognostic Marker in Early Gastric Cancer, But Not in Advanced Gastric Cancer. Cancer Res. Treat. 2016, 48, 142-152. [CrossRef]

169. Auvinen, P.; Tammi, R.; Kosma, V.-M.; Sironen, R.; Soini, Y.; Mannermaa, A.; Tumelius, R.; Uljas, E.; Tammi, M. Increased hyaluronan content and stromal cell CD44 associate withHER2positivity and poor prognosis in human breast cancer. Int. J. Cancer 2013, 132, 531-539. [CrossRef]

170. Goldoni, S.; Owens, R.T.; McQuillan, D.J.; Shriver, Z.; Sasisekharan, R.; Birk, D.E.; Campbell, S.; Iozzo, R.V. Biologically Active Decorin Is a Monomer in Solution. J. Biol. Chem. 2004, 279, 6606-6612. [CrossRef]

171. Neill, T.; Torres, A.; Buraschi, S.; Iozzo, R.V. Decorin has an appetite for endothelial cell autophagy. Autophagy 2013, 9, 1626-1628. [CrossRef] [PubMed]

172. Yamaguchi, Y.; Mann, D.M.; Ruoslahti, E. Negative regulation of transforming growth factor- $\beta$ by the proteoglycan decorin. Nature 1990, 346, 281-284. [CrossRef] [PubMed]

173. Gatza, C.E.; Oh, S.Y.; Blobe, G.C. Roles for the type III TGF-beta receptor in human cancer. Cell Signal. 2010, 22, 1163-1174. [CrossRef] [PubMed]

174. Elfenbein, A.; Simons, M. Syndecan-4 signaling at a glance. J. Cell Sci. 2013, 126, 3799-3804. [CrossRef]

175. Derksen, P.W.; Keehnen, R.M.; Evers, L.M.; van Oers, M.H.; Spaargaren, M.; Pals, S.T. Cell surface proteoglycan syndecan-1 mediates hepatocyte growth factor binding and promotes Met signaling in multiple myeloma. Blood 2002, 99, 1405-1410. [CrossRef]

176. Wang, H.; Jin, H.; Beauvais, D.M.; Rapraeger, A.C. Cytoplasmic Domain Interactions of Syndecan-1 and Syndecan-4 with $\alpha 6 \beta 4$ Integrin Mediate Human Epidermal Growth Factor Receptor (HER1 and HER2)-dependent Motility and Survival. J. Biol. Chem. 2014, 289, 30318-30332. [CrossRef]

177. Mongiat, M.; Otto, J.; Oldershaw, R.; Ferrer, F.; Sato, J.D.; Iozzo, R.V. Fibroblast Growth Factor-binding Protein Is a Novel Partner for Perlecan Protein Core. J. Biol. Chem. 2001, 276, 10263-10271. [CrossRef]

178. Lord, M.S.; Chuang, C.Y.; Melrose, J.; Davies, M.J.; Iozzo, R.V.; Whitelock, J.M. The role of vascular-derived perlecan in modulating cell adhesion, proliferation and growth factor signaling. Matrix Biol. 2014, 35, 112-122. [CrossRef]

179. Park, C.R.; You, D.J.; Kim, D.K.; Moon, M.J.; Lee, C.; Oh, S.-H.; Ahn, C.; Seong, J.Y.; Hwang, J.-I. CXCL14 enhances proliferation and migration of NCI-H460 human lung cancer cells overexpressing the glycoproteins containing heparan sulfate or sialic acid. J. Cell Biochem. 2013, 114, 1084-1096. [CrossRef] 
180. Tuccillo, F.M.; Palmieri, C.; Fiume, G.; de Laurentiis, A.; Schiavone, M.; Falcone, C.; Iaccino, E.; Galandrini, R.; Capuano, C.; Santoni, A.; et al. Cancer-associated CD43 glycoforms as target of immunotherapy. Mol. Cancer Ther. 2014, 13, 752-762. [CrossRef]

181. de Laurentiis, A.; Gaspari, M.; Palmieri, C.; Falcone, C.; Iaccino, E.; Fiume, G.; Massa, O.; Masullo, M.; Tuccillo, F.M.; Roveda, L.; et al. Mass Spectrometry-Based Identification Of The Tumor Antigen UN1 as the Transmembrane CD43 Sialoglycoprotein. Mol. Cell. Proteom. 2011, 10, M1111.007898. [CrossRef] [PubMed]

182. Balikova, A.; Jääger, K.; Viil, J.; Maimets, T.; Kadaja-Saarepuu, L. Leukocyte marker CD43 promotes cell growth in co-operation with $\beta$-catenin in non-hematopoietic cancer cells. Int. J. Oncol. 2012, 41, 299-309. [CrossRef] [PubMed]

183. Kadaja-Saarepuu, L.; Laos, S.; Jääger, K.; Viil, J.; Balikova, A.; Lõoke, M.; Hansson, G.C.; Maimets, T. CD43 promotes cell growth and helps to evade FAS-mediated apoptosis in non-hematopoietic cancer cells lacking the tumor suppressors p53 or ARF. Oncogene 2008, 27, 1705-1715. [CrossRef] [PubMed]

184. Tuccillo, F.M.; de Laurentiis, A.; Palmieri, C.; Fiume, G.; Bonelli, P.; Borrelli, A.; Tassone, P.; Scala, I.; Buonaguro, F.M.; Quinto, I.; et al. Aberrant Glycosylation as Biomarker for Cancer: Focus on CD43. BioMed Res. Int. 2014, 2014, 742831. [CrossRef] [PubMed]

185. Hirose, J.; Kawashima, H.; Yoshie, O.; Tashiro, K.; Miyasaka, M. Versican Interacts with Chemokines and Modulates Cellular Responses. J. Biol. Chem. 2001, 276, 5228-5234. [CrossRef] [PubMed]

186. Toole, B.P.; Slomiany, M.G. Hyaluronan, CD44 and Emmprin: Partners in cancer cell chemoresistance. Drug Resist. Updat. 2008, 11, 110-121. [CrossRef]

187. Chanmee, T.; Ontong, P.; Kimata, K.; Itano, N. Key Roles of Hyaluronan and Its CD44 Receptor in the Stemness and Survival of Cancer Stem Cells. Front. Oncol. 2015, 5, 180. [CrossRef]

188. Price, D.; Muterspaugh, R.; Clegg, B.; Williams, A.; Stephens, A.; Guthrie, J.; Heyl, D.; Evans, H.G. IGFBP-3 Blocks Hyaluronan-CD44 Signaling, Leading to Increased Acetylcholinesterase Levels in A549 Cell Media and Apoptosis in a p53-Dependent Manner. Sci. Rep. 2020, 10, 1-17. [CrossRef]

189. Qin, Z.; Dai, L.; Bratoeva, M.; Slomiany, M.G.; Toole, B.P.; Parsons, C. Cooperative roles for emmprin and LYVE-1 in the regulation of chemoresistance for primary effusion lymphoma. Leukemia 2011, 25, 1598-1609. [CrossRef]

190. Saban, M.R.; Mémet, S.; Jackson, D.G.; Ash, J.; Roig, A.A.; Israël, A.; Saban, R. Visualization of lymphatic vessels through NF-kappaB activity. Blood 2004, 104, 3228-3230. [CrossRef]

191. Tang, Y.; Nakada, M.T.; Rafferty, P.; Laraio, J.; McCabe, F.L.; Millar, H.; Cunningham, M.; Snyder, L.A.; Bugelski, P.; Yan, L. Regulation of Vascular Endothelial Growth Factor Expression by EMMPRIN via the PI3K-Akt Signaling Pathway. Mol. Cancer Res. 2006, 4, 371-377. [CrossRef] [PubMed]

192. Paolillo, M.; Schinelli, S. Extracellular Matrix Alterations in Metastatic Processes. Int. J. Mol. Sci. 2019, $20,4947$. [CrossRef] [PubMed]

193. Brauchle, E.; Kasper, J.; Daum, R.; Schierbaum, N.; Falch, C.; Kirschniak, A.; Schäffer, T.E.; Schenke-Layland, K. Biomechanical and biomolecular characterization of extracellular matrix structures in human colon carcinomas. Matrix Biol. 2018, 68, 180-193. [CrossRef] [PubMed]

194. Suhovskih, A.V.; Mostovich, L.A.; Kunin, I.S.; Boboev, M.M.; Nepomnyashchikh, G.I.; Aidagulova, S.V.; Grigorieva, E.V. Proteoglycan Expression in Normal Human Prostate Tissue and Prostate Cancer. ISRN Oncol. 2013, 2013, 680136. [CrossRef]

195. Menard, J.A.; Christianson, H.C.; Kucharzewska, P.; Bourseau-Guilmain, E.; Svensson, K.J.; Lindqvist, E.; Chandran, V.I.; Kjellén, L.; Welinder, C.; Bengzon, J.; et al. Metastasis stimulation by hypoxia and acidosis-induced extracellular lipid uptake is mediated by proteoglycan-dependent endocytosis. Cancer Res. 2016, 76, 4828-4840. [CrossRef]

196. Salazar-Roa, M.; Malumbres, M. Fueling the Cell Division Cycle. Trends Cell Biol. 2017, 27, 69-81. [CrossRef]

197. Bertero, T.; Oldham, W.M.; Grasset, E.M.; Bourget, I.; Boulter, E.; Pisano, S.; Hofman, P.; Bellvert, F.; Meneguzzi, G.; Bulavin, D.V.; et al. Tumor-Stroma Mechanics Coordinate Amino Acid Availability to Sustain Tumor Growth and Malignancy. Cell Metab. 2019, 29, 124-140.e10. [CrossRef]

198. Sullivan, W.J.; Mullen, P.J.; Schmid, E.W.; Flores, A.; Momcilovic, M.; Sharpley, M.S.; Jelinek, D.; Whiteley, A.E.; Maxwell, M.B.; Wilde, B.R.; et al. Extracellular Matrix Remodeling Regulates Glucose Metabolism through TXNIP Destabilization. Cell 2018, 175, 117-132.e21. [CrossRef] 
199. Marieb, E.A.; Zoltan-Jones, A.; Li, R.; Misra, S.; Ghatak, S.; Cao, J.; Zucker, S.; Toole, B.P. Emmprin Promotes Anchorage-Independent Growth in Human Mammary Carcinoma Cells by Stimulating Hyaluronan Production. Cancer Res. 2004, 64, 1229-1232. [CrossRef]

200. Slomiany, M.G.; Grass, G.D.; Robertson, A.D.; Yang, X.Y.; Maria, B.L.; Beeson, C.; Toole, B.P. Hyaluronan, $\mathrm{CD} 44$, and emmprin regulate lactate efflux and membrane localization of monocarboxylate transporters in human breast carcinoma cells. Cancer Res. 2009, 69, 1293-1301. [CrossRef]

201. Fang, Y.; Shen, Z.Y.; Zhan, Y.Z.; Feng, X.C.; Chen, K.L.; Li, Y.; Deng, H.-J.; Pan, S.M.; Wu, D.-H.; Ding, Y. CD36 inhibits $\beta$-catenin/c-myc-mediated glycolysis through ubiquitination of GPC4 to repress colorectal tumorigenesis. Nat. Commun. 2019, 10,1-6. [CrossRef] [PubMed]

202. Lin, R.; Xia, S.; Shan, C.; Chen, D.; Liu, Y.; Gao, X.; Wang, M.; Kang, H.-B.; Pan, Y.; Liu, S.; et al. The Dietary Supplement Chondroitin-4-Sulfate Exhibits Oncogene-Specific Pro-tumor Effects on BRAF V600E Melanoma Cells. Mol. Cell 2018, 69, 923-937.e8. [CrossRef] [PubMed]

203. Nakayama, F.; Umeda, S.; Ichimiya, T.; Kamiyama, S.; Hazawa, M.; Yasuda, T.; Nishihara, S.; Imai, T. Sulfation of keratan sulfate proteoglycan reduces radiation-induced apoptosis in human Burkitt's lymphoma cell lines. FEBS Lett. 2013, 587, 231-237. [CrossRef] [PubMed]

204. Kato, Y.; Hayatsu, N.; Kaneko, M.K.; Ogasawara, S.; Hamano, T.; Takahashi, S.; Nishikawa, R.; Matsutani, M.; Mishima, K.; Narimatsu, H. Increased expression of highly sulfated keratan sulfate synthesized in malignant astrocytic tumors. Biochem. Biophys. Res. Commun. 2008, 369, 1041-1046. [CrossRef] [PubMed]

205. Hayatsu, N.; Ogasawara, S.; Kaneko, M.K.; Kato, Y.; Narimatsu, H. Expression of highly sulfated keratan sulfate synthesized in human glioblastoma cells. Biochem. Biophys. Res. Commun. 2008, 368, 217-222. [CrossRef] [PubMed]

206. Bat-Erdene, U.; Quan, E.; Chan, K.; Lee, B.-M.; Matook, W.; Lee, K.-Y.; Rosales, J.L. Neutrophil TLR4 and PKR are targets of breast cancer cell glycosaminoglycans and effectors of glycosaminoglycan-induced APRIL secretion. Oncogenesis 2018, 7, 45. [CrossRef]

207. Xing, X.; Gu, X.; Ma, T. Knockdown of biglycan expression by RNA interference inhibits the proliferation and invasion of, and induces apoptosis in, the HCT116 colon cancer cell line. Mol. Med. Rep. 2015, 12, 7538-7544. [CrossRef]

208. Brézillon, S.; Radwanska, A.; Zeltz, C.; Malkowski, A.; Ploton, M.; Bobichon, H.; Perreau, C.; Malicka-Blaszkiewicz, M.; Maquart, F.-X.; Wegrowski, Y. Lumican core protein inhibits melanoma cell migration via alterations of focal adhesion complexes. Cancer Lett. 2009, 283, 92-100. [CrossRef]

209. Zeltz, C.; Brézillon, S.; Käpylä, J.; Eble, J.A.; Bobichon, H.; Terryn, C.; Perreau, C.; Franz, C.M.; Heino, J.; Maquart, F.-X.; et al. Lumican inhibits cell migration through $\alpha 2 \beta 1$ integrin. Exp. Cell Res. 2010, 316, 2922-2931. [CrossRef]

210. Jeanne, A.; Untereiner, V.; Perreau, C.; Proult, I.; Gobinet, C.; Boulagnon-Rombi, C.; Terryn, C.; Martiny, L.; Brézillon, S.; Dedieu, S. Lumican delays melanoma growth in mice and drives tumor molecular assembly as well as response to matrix-targeted TAX2 therapeutic peptide. Sci. Rep. 2017, 7, 1-16. [CrossRef]

211. Whitelock, J.M.; Melrose, J.; Iozzo, R.V. Diverse Cell Signaling Events Modulated by Perlecan. Biochemistry 2008, 47, 11174-11183. [CrossRef]

212. Shi, J.; Fan, C.; Zhuang, Y.; Sun, J.; Hou, X.; Chen, B.; Xiao, Z.; Chen, Y.; Zhan, Z.; Zhao, Y.; et al. Heparan sulfate proteoglycan promotes fibroblast growth factor-2 function for ischemic heart repair. Biomater. Sci. 2019, 7, 5438-5450. [CrossRef]

213. Karamanos, N.K.; Piperigkou, Z.; Theocharis, A.D.; Watanabe, H.; Franchi, M.; Baud, S.; Brézillon, S.; Götte, M.; Passi, A.; Vigetti, D.; et al. Proteoglycan Chemical Diversity Drives Multifunctional Cell Regulation and Therapeutics. Chem. Rev. 2018, 118, 9152-9232. [CrossRef] [PubMed]

214. Sottile, J. Regulation of angiogenesis by extracellular matrix. Biochim. Biophys. Acta BBA Rev. Cancer 2004, 1654, 13-22. [CrossRef] [PubMed]

215. Andreuzzi, E.; Capuano, A.; Poletto, E.; Pivetta, E.; Fejza, A.; Favero, A.; Doliana, R.; Cannizzaro, R.; Spessotto, P.; Mongiat, M. Role of Extracellular Matrix in Gastrointestinal Cancer-Associated Angiogenesis. Int. J. Mol. Sci. 2020, 21, 3686. [CrossRef] [PubMed]

216. West, D.C.; Hampson, I.N.; Arnold, F.; Kumar, S. Angiogenesis induced by degradation products of hyaluronic acid. Science 1985, 228, 1324-1326. [CrossRef] 
217. Kobayashi, N.; Miyoshi, S.; Mikami, T.; Koyama, H.; Kitazawa, M.; Takeoka, M.; Sano, K.; Amano, J.; Isogai, Z.; Niida, S.; et al. Hyaluronan Deficiency in Tumor Stroma Impairs Macrophage Trafficking and Tumor Neovascularization. Cancer Res. 2010, 70, 7073-7083. [CrossRef]

218. Koyama, H.; Hibi, T.; Isogai, Z.; Yoneda, M.; Fujimori, M.; Amano, J.; Kawakubo, M.; Kannagi, R.; Kimata, K.; Taniguchi, S.; et al. Hyperproduction of Hyaluronan in Neu-Induced Mammary Tumor Accelerates Angiogenesis through Stromal Cell Recruitment: Possible involvement of versican/PG-M. Am. J. Pathol. 2007, 170, 1086-1099. [CrossRef]

219. Asano, K.; Nelson, C.M.; Nandadasa, S.; Aramaki-Hattori, N.; Lindner, D.J.; Alban, T.; Inagaki, J.; Ohtsuki, T.; Oohashi, T.; Apte, S.S.; et al. Stromal Versican Regulates Tumor Growth by Promoting Angiogenesis. Sci. Rep. 2017, 7, 17225. [CrossRef]

220. Hu, L.; Zang, M.-D.; Wang, H.-X.; Li, J.-F.; Su, L.-P.; Yan, M.; Li, C.; Yang, Q.-M.; Liu, B.-Y.; Zhu, Z. Biglycan stimulates VEGF expression in endothelial cells by activating the TLR signaling pathway. Mol. Oncol. 2016, 10, 1473-1484. [CrossRef]

221. Gubbiotti, M.A.; Neill, T.; Iozzo, R.V. A current view of perlecan in physiology and pathology: A mosaic of functions. Matrix Biol. 2017, 57, 285-298. [CrossRef] [PubMed]

222. Theocharis, A.D.; Skandalis, S.S.; Tzanakakis, G.N.; Karamanos, N.K. Proteoglycans in health and disease: Novel roles for proteoglycans in malignancy and their pharmacological targeting. FEBS J. 2010, 277, 3904-3923. [CrossRef] [PubMed]

223. Whipple, C.A.; Young, A.L.; Korc, M. A KrasG12D-driven genetic mouse model of pancreatic cancer requires glypican-1 for efficient proliferation and angiogenesis. Oncogene 2012, 31, 2535-2544. [CrossRef] [PubMed]

224. Chaki, S.P.; Barhoumi, R.; Rivera, G.M. Nck adapter proteins promote podosome biogenesis facilitating extracellular matrix degradation and cancer invasion. Cancer Med. 2019, 8, 7385-7398. [CrossRef]

225. Gatto, F.; Volpi, N.; Nilsson, H.; Nookaew, I.; Maruzzo, M.; Roma, A.; Johansson, M.E.; Stierner, U.; Lundstam, S.; Basso, U.; et al. Glycosaminoglycan Profiling in Patients' Plasma and Urine Predicts the Occurrence of Metastatic Clear Cell Renal Cell Carcinoma. Cell Rep. 2016, 15, 1822-1836. [CrossRef] [PubMed]

226. Itano, N.; Atsumi, F.; Sawai, T.; Yamada, Y.; Miyaishi, O.; Senga, T.; Hamaguchi, M.; Kimata, K. Abnormal accumulation of hyaluronan matrix diminishes contact inhibition of cell growth and promotes cell migration. Proc. Natl. Acad. Sci. USA 2002, 99, 3609-3614. [CrossRef]

227. Strutz, F.; Zeisberg, M.; Ziyadeh, F.N.; Yang, C.-Q.; Kalluri, R.; Müller, G.A.; Neilson, E.G.; Renziehausen, A.; Sisic, Z. Role of basic fibroblast growth factor-2 in epithelial-mesenchymal transformation. Kidney Int. 2002, 61, 1714-1728. [CrossRef]

228. Mizumoto, S.; Takahashi, J.; Sugahara, K. Receptor for advanced glycation end products (RAGE) functions as receptor for specific sulfated glycosaminoglycans, and anti-RAGE antibody or sulfated glycosaminoglycans delivered in vivo inhibit pulmonary metastasis of tumor cells. J. Biol. Chem. 2012, 287, 18985-18994. [CrossRef]

229. Kim, S.; Takahashi, H.; Lin, W.-W.; Descargues, P.; Grivennikov, S.; Kim, Y.; Luo, J.-L.; Karin, M. Carcinoma-produced factors activate myeloid cells through TLR2 to stimulate metastasis. Nature 2009, 457, 102-106. [CrossRef]

230. Yang, N.; Mosher, R.; Seo, S.; Beebe, D.; Friedl, A. Syndecan-1 in Breast Cancer Stroma Fibroblasts Regulates Extracellular Matrix Fiber Organization and Carcinoma Cell Motility. Am. J. Pathol. 2011, 178, 325-335. [CrossRef]

231. Guo, J.-Y.; Chiu, C.-H.; Wang, M.-J.; Li, F.-A.; Chen, J.-Y. Proteoglycan serglycin promotes non-small cell lung cancer cell migration through the interaction of its glycosaminoglycans with CD44. J. Biomed. Sci. 2020, 27, 2-18. [CrossRef] [PubMed]

232. Kuczek, D.E.; Larsen, A.; Thorseth, M.L.; Carretta, M.; Kalvisa, A.; Siersbæk, M.S.; Simões, A.M.C.; Roslind, A.; Engelholm, L.H.; Noessner, E.; et al. Collagen density regulates the activity of tumor-infiltrating T cells. J. Immunother. Cancer 2019, 7, 68. [CrossRef] [PubMed]

233. Kuang, D.-M.; Zhao, Q.; Xu, J.; Yun, J.-P.; Wu, C.; Zheng, L. Tumor-educated tolerogenic dendritic cells induce CD3epsilon down-regulation and apoptosis of T cells through oxygen-dependent pathways. J. Immunol. 2008, 181, 3089-3098. [CrossRef] [PubMed]

234. Katoh, H.; Komura, D.; Konishi, H.; Suzuki, R.; Yamamoto, A.; Kakiuchi, M.; Sato, R.; Ushiku, T.; Yamamoto, S.; Tatsuno, K.; et al. Immunogenetic Profiling for Gastric Cancers Identifies Sulfated Glycosaminoglycans as Major and Functional B Cell Antigens in Human Malignancies. Cell Rep. 2017, 20, 1073-1087. [CrossRef] 
235. Yasuda, M.; Tanaka, Y.; Fujii, K.; Yasumoto, K. CD44 stimulation down-regulates Fas expression and Fas-mediated apoptosis of lung cancer cells. Int. Immunol. 2001, 13, 1309-1319. [CrossRef]

236. Hickey, J.W.; Dong, Y.; Chung, J.W.; Salathe, S.F.; Pruitt, H.C.; Li, X.; Chang, C.; Fraser, A.K.; Bessell, C.A.; Ewald, A.J.; et al. Engineering an Artificial T-Cell Stimulating Matrix for Immunotherapy. Adv. Mater. 2019, 31, e1807359. [CrossRef]

237. Hope, C.; Emmerich, P.B.; Papadas, A.; Pagenkopf, A.; Matkowskyj, K.A.; van de Hey, D.R.; Payne, S.N.; Clipson, L.; Callander, N.S.; Hematti, P.; et al. Versican-Derived Matrikines Regulate Batf3-Dendritic Cell Differentiation and Promote T Cell Infiltration in Colorectal Cancer. J. Immunol. 2017, 199, 1933-1941. [CrossRef]

238. Cherfils-Vicini, J.; Iltis, C.; Cervera, L.; Pisano, S.; Croce, O.; Sadouni, N.; Győrffy, B.; Collet, R.; Renault, V.M.; Rey-Millet, M.; et al. Cancer cells induce immune escape via glycocalyx changes controlled by the telomeric protein TRF 2. EMBO J. 2019, 38, e100012. [CrossRef]

239. Miyamoto, T.; Ishii, K.; Asaka, R.; Suzuki, A.; Takatsu, A.; Kashima, H.; Shiozawa, T. Immunohistochemical expression of keratan sulfate: A possible diagnostic marker for carcinomas of the female genital tract. J. Clin. Pathol. 2011, 64, 1058-1063. [CrossRef]

240. Melo, S.A.; Luecke, L.B.; Kahlert, C.; Fernández, A.F.; Gammon, S.T.; Kaye, J.; LeBleu, V.S.; Mittendorf, E.A.; Weitz, J.; Rahbari, N.; et al. Glypican-1 identifies cancer exosomes and detects early pancreatic cancer. Nature 2015, 523, 177-182. [CrossRef]

241. Yip, G.W.; Smollich, M.; Götte, M. Therapeutic value of glycosaminoglycans in cancer. Mol. Cancer Ther. 2006, 5, 2139-2148. [CrossRef]

242. Toole, B.P. Hyaluronan: From extracellular glue to pericellular cue. Nat. Rev. Cancer 2004, 4, 528-539. [CrossRef] [PubMed]

243. Kultti, A.; Li, X.; Jiang, P.; Thompson, C.B.; Frost, G.I.; Shepard, H.M. Therapeutic Targeting of Hyaluronan in the Tumor Stroma. Cancers 2012, 4, 873-903. [CrossRef] [PubMed]

244. Bourguignon, L.; Earle, C.; Shiina, M. Activation of Matrix Hyaluronan-Mediated CD44 Signaling, Epigenetic Regulation and Chemoresistance in Head and Neck Cancer Stem Cells. Int. J. Mol. Sci. 2017, 18, 1849. [CrossRef] [PubMed]

245. Chokchaitaweesuk, C.; Kobayashi, T.; Izumikawa, T.; Itano, N. Enhanced hexosamine metabolism drives metabolic and signaling networks involving hyaluronan production and O-GlcNAcylation to exacerbate breast cancer. Cell Death Dis. 2019, 10, 803-815. [CrossRef]

246. Zhang, H.; Ren, L.; Ding, Y.; Li, F.; Chen, X.; Ouyang, Y.; Zhang, Y.; Zhang, D. Hyaluronan-mediated motility receptor confers resistance to chemotherapy via TGF $\beta / S m a d 2-i n d u c e d$ epithelial-mesenchymal transition in gastric cancer. FASEB J. 2019, 33, 6365-6377. [CrossRef]

247. Shepard, H.M. Breaching the Castle Walls: Hyaluronan Depletion as a Therapeutic Approach to Cancer Therapy. Front. Oncol. 2015, 5, 192. [CrossRef]

248. Singha, N.C.; Nekoroski, T.; Zhao, C.; Symons, R.; Jiang, P.; Frost, G.I.; Huang, Z.; Shepard, H.M.; Goglia, A.G.; Delsite, R.; et al. Tumor-Associated Hyaluronan Limits Efficacy of Monoclonal Antibody Therapy. Mol. Cancer Ther. 2015, 14, 523-532. [CrossRef]

249. Ma, M.; Weng, M.; Zhang, M.; Qin, Y.; Gong, W.; Quan, Z. Targeting gallbladder cancer: Hyaluronan sensitizes cancer cells to chemo-therapeutics. Int. J. Clin. Exp. Pathol. 2015, 8, 1822-1825.

250. Huang, G.; Huang, H. Application of hyaluronic acid as carriers in drug delivery. Drug Deliv. 2018, 25, 766-772. [CrossRef]

251. Huang, G.; Huang, H. Hyaluronic acid-based biopharmaceutical delivery and tumor-targeted drug delivery system. J. Control. Release 2018, 278, 122-126. [CrossRef] [PubMed]

252. Xu, W.; Neill, T.; Yang, Y.; Hu, Z.; Cleveland, E.; Wu, Y.; Hutten, R.; Xiao, X.; Stock, S.R.; Shevrin, D.; et al. The systemic delivery of an oncolytic adenovirus expressing decorin inhibits bone metastasis in a mouse model of human prostate cancer. Gene Ther. 2015, 22, 247-256. [CrossRef] [PubMed]

253. Arichi, N.; Mitsui, Y.; Hiraki, M.; Nakamura, S.; Hiraoka, T.; Sumura, M.; Hirata, H.; Tanaka, Y.; Dahiya, R.; Yasumoto, H.; et al. Versican is a potential therapeutic target in docetaxel-resistant prostate cancer. Oncoscience 2015, 2, 193-204. [CrossRef] [PubMed] 
254. Eng, M.S.; Kaur, J.; Prasmickaite, L.; Engesæter, B.Ø.; Weyergang, A.; Skarpen, E.; Berg, K.; Rosenblum, M.G.; Mælandsmo, G.M.; Hogset, A.; et al. Enhanced targeting of triple-negative breast carcinoma and malignant melanoma by photochemical internalization of CSPG4-targeting immunotoxins. Photochem. Photobiol. Sci. 2018, 17, 539-551. [CrossRef]

255. Pucciarelli, D.; Lengger, N.; Takacova, M.; Csaderova, L.; Bartosova, M.; Breiteneder, H.; Pastorekova, S.; Hafner, C. Anti-chondroitin sulfate proteoglycan 4-specific antibodies modify the effects of vemurafenib on melanoma cells differentially in normoxia and hypoxia. Int. J. Oncol. 2015, 47, 81-90. [CrossRef]

256. Du, W.W.; Fang, L.; Yang, X.; Sheng, W.; Seth, A.; Zhang, Y.; Yee, A.J.M. The Role of Versican in Modulating Breast Cancer Cell Self-renewal. Mol. Cancer Res. 2013, 11, 443-455. [CrossRef]

257. Wang, X.; Zuo, D.; Chen, Y.; Li, W.; Liu, R.; He, Y.; Ren, L.; Zhou, L.; Deng, T.; Ying, G.; et al. Shed Syndecan-1 is involved in chemotherapy resistance via the EGFR pathway in colorectal cancer. Br. J. Cancer 2014, 111, 1965-1976. [CrossRef]

258. Espinoza-Sánchez, N.A.; Götte, M. Role of cell surface proteoglycans in cancer immunotherapy. Semin. Cancer Biol. 2020, 62, 48-67. [CrossRef]

259. Byeon, Y.; Lee, J.-W.; Choi, W.S.; Won, J.E.; Kim, G.H.; Kim, M.G.; Wi, T.I.; Lee, J.M.; Kang, T.H.; Jung, I.D.; et al. CD44-Targeting PLGA Nanoparticles Incorporating Paclitaxel and FAK siRNA Overcome Chemoresistance in Epithelial Ovarian Cancer. Cancer Res. 2018, 78, 6247-6256. [CrossRef]

(C) 2020 by the authors. Licensee MDPI, Basel, Switzerland. This article is an open access article distributed under the terms and conditions of the Creative Commons Attribution (CC BY) license (http://creativecommons.org/licenses/by/4.0/). 